\title{
JINETES EN GRECIA Y SUS ECOS EN LA CULTURA IBÉRICA
}

\author{
POR
}

ADOLFO J. DOMÍNGUEZ MONEDERO

\section{RESUMEN - ABSTRACT}

Se pasa revista a los usos del caballo en Grecia desde época micénica hasta el final del Clasicismo a fin de observar su desarrollo como arma militar. Además, se estudia también la proyección social del uso del caballo en Grecia así como el desarrollo de competiciones ecuestres que sirvieron también como medio de exhibir el estatus social de los grupos dirigentes de las poleis griegas. En el capítulo final se consideran también los posibles ecos de los usos del caballo en Grecia en el mundo ibérico, aunque estas posibles relaciones se limitan sobre todo a préstamos iconográficos de modelos griegos a algunas manifestaciones artísticas ibéricas.

The uses of the horse in Greece are reviewed from the Mycenaean until Late Classical times in order to trace its development as a military weapon. Besides, the social projection of the use of the horse in Greece is also addressed, as well as the development of equestrian contests which served also as a means of stressing the social status of the leading groups within the Greek poleis. In a final chapter the possible reflections of the uses of the horse in Greece in the Iberian world are also considered, although the possible relationships are confined mainly to iconographical loans from Greek prototypes to some Iberian artistic manifestations.

\section{PALABRAS CLAVE - KEY WORDS}

Caballos, Caballería, Jinetes. Grecia, Iberia.

Horses. Cavalry, Horsemen, Greece, Iberia.

\section{USOS DEL CABALLO EN GRECIA.}

Abordar un análisis, siquiera breve, del empleo que los griegos hacen del caballo es una tarea no del todo fácil, habida cuenta una serie de problemas entre los cuales no es el menos importante lo tardías que son las primeras reflexiones teóricas y metodológicas sobre su uso, que no parecen haber sido anteriores a los años finales del siglo $\mathrm{V}$ cuando el ateniense Simón compuso un tratado sobre el aspecto y la selección de los caballos, sólo conservado en parte, aunque habrá que esperar al siglo IV a.C. cuando otro ateniense, Jenofonte, además de sus relatos históricos en los que la caballería aparece en acción, escribe sus dos obras principales sobre el tema, el Hipparchikos o «Sobre el jefe de la caballería» y Peri Hippikes o «Sobre la equitación». Antes de ese momento, no obstante, las referencias a los caballos y a sus jinetes en distintas fuentes, tanto literarias, epigráficas, arqueológicas e iconográficas son bastante abundantes lo que demuestra el uso y el aprecio que el mundo griego siente hacia ambos antes de la época del mencionado autor. Además, y lo que es más relevante, el uso de la caballería como arma de guerra se revela cada vez más importante, al menos en algunas ciuda- 
des y territorios de Grecia a lo largo de toda su historia y, en muchas otras, no demasiado aptas para una cría caballar a gran escala, el individuo montado a caballo será siempre un referente social, aun cuando no siempre militar, a tener en cuenta.

Esto nos lleva a los usos del caballo en Grecia. Prescindiré en este trabajo de los usos como animal de trabajo y me centraré en su utilización desde las perspectivas militar, religiosa o de aparato, y deportiva que son las que más hacen justicia a la utilización del caballo y su montura en el mundo griego. Mi estudio lo agruparé en los diferentes periodos cronológicos en que por lo general se divide la historia griega. Al final haré algunas observaciones acerca de cómo la percepción del caballo en Grecia puede haber llegado, en ocasiones, a introducir ciertos matices a su uso en el mundo ibérico.

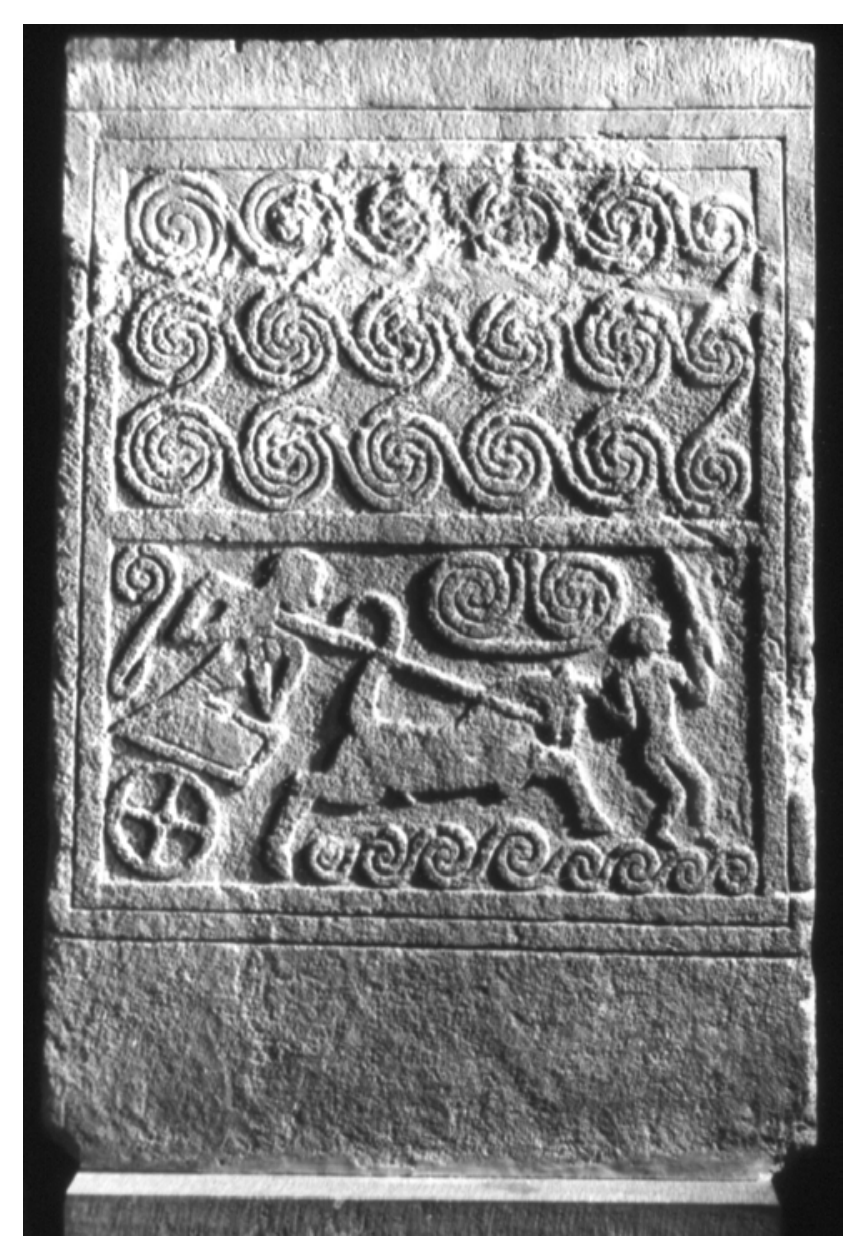

Figura 1. Estela del círculo A de tumbas de Micenas.

\subsection{La época micénica: carros al estilo oriental.}

La Grecia micénica hizo uso del caballo desde el punto de vista militar, aunque su utilización prioritaria parece haber sido para tirar de carros de guerra. Ya en alguna de las estelas del círculo A de tumbas de Micenas aparecen representadas escenas de guerreros montados en carros que atacan desde ellos con lanzas a sus enemigos (Figura 1) y, en algunas joyas 
halladas en las tumbas aparecen, asimismo, escenas de caza de animales salvajes sobre carros. Para la época palacial disponemos de dos tipos de testimonios. Por un lado, los iconográficos que, en algunas ocasiones, nos muestran un carro ligero con una caja en apariencia bastante liviana y un solo eje, y tirado por una pareja de caballos (Crouwel, 1992; Giesecke, 1988-89: 17-39) (Figura 2). Mucha más información nos proporciona la documentación escrita en lineal B procedente de los palacios de Cnoso y de Pilo sobre todo. En el caso de Cnoso las tablillas mencionan hasta 550 cajas de carros y sus correspondientes pares de ruedas, puesto que parece que los dos componentes principales de los carros se almacenaban desmontados (Lejeune, 1968: 9-61; Uchitel, 1988: 47-58). Del mismo modo, en el palacio de Pilo se mencionan en torno a los doscientos pares de ruedas así como madera para construir 150 ejes. En el palacio de Cnoso, la mayor parte de las tablillas referidas a carros se hallaron en una misma estancia, bautizada por ello como la «Estancia de las tablillas de carros» (Room of the Chariot Tablets); aunque no todos los documentos en lineal B hallados en la misma aludían a carros sí al menos la tercera parte de ellos (sobre todo las series Sc y Vc), que se refieren a asignaciones de carros, caballos y armamento a una serie de individuos; las vinculaciones religiosas del contenido de la sala también se han puesto de manifiesto en alguna ocasión (Driessen, 1986-87: 151-162; Id., 1988: 123-156; Gulizio, Pluta y Palaima, 2001: 453-461).

$\mathrm{Ni}$ que decir tiene que los reinos micénicos no podían poner en el campo de batalla los miles de carros que los grandes imperios orientales podían desplegar pero, no obstante, una fuerza compuesta de algunos centenares de carros no dejaba de ser un elemento importante en la táctica militar micénica, fuese cual fuese ésta (Drews, 1993: 113-129; Littauer, 1972: 145-157; Littauer y Crouwel, 1983: 187-192; Id., 1996: 297-305). Por ende, el hecho de que la burocracia palacial contabilizase los elementos almacenados muestra, fuera de toda duda, que eran los propios palacios quienes se preocupaban de que esta importante arma estuviese lo más dispuesta posible para su eventual uso; la mención a constructores de carros en alguna tablilla de Pilo (PY En 421 y En 809) indica asimismo el interés del palacio en la fabricación y el mantenimiento de los mismos. Del mismo modo, la presencia de los carros sugiere la existencia no sólo de guerreros y aurigas sino también de toda una serie de individuos dedicados a las reparaciones, como ya hemos visto, pero también a la atención y cuidado de los caballos que eran una parte imprescindible del equipo bélico. En el sistema de escritura de los palacios micénicos, el lineal B, había un ideograma específico para representar al carro, así como otro para representar las ruedas y, por fin, otro para el caballo (Doria, 1972; Ruijgh, 1976; Bernabé, 1996: 195-207) (Figura 3).

Los restos óseos equinos estudiados presentan un caballo de una alzada no muy elevada (en torno a 1,35 y 1,45 m.) (Sloan y Duncan, 1978: 60-77; Payne, 1990: 103-106). En ocasiones han aparecido, sobre todo en tumbas, restos completos de caballos con frecuencia en parejas, lo que podría sugerir que, al ser enterrados como ofrenda o sacrificio funerario se pretendía que pudieran seguir ejerciendo en el más allá la misma función que desempeñaban en vida. Casos destacados son, por ejemplo, los de Dendra, donde se hallaron en dos enterramientos diferentes (túmulo B y túmulo $\mathrm{C}$ ) sendas parejas de caballos. En los cuatro casos se trata de machos de en torno a 15 años y de una alzada entre 1,35 y 1,40 m.; mientras que los del túmulo C datan del Heládico Medio, los del B son posteriores, datándose en el Heládico Reciente I. Fueron enterrados completos y su excavadora sugiere que formaron parte del tiro de un carro en vida, a pesar de que no se han hallado restos de dicho vehículo (Protonotariou-Deilaki, 1990: 85-106).

De un momento algo posterior (Heládico Reciente IIB, entre ca. 1450 y 1380 a.C.) es otro par de caballos que fueron enterrados a la entrada del dromos de una tholos excavada en Arnos, Maratón; aparecían con las cabezas orientadas hacia la entrada de la tumba en posición anatómica y está claro su carácter de ofrenda ritual y sacrificial (Petrakos, 1996: 63-65) (Figura 4). 


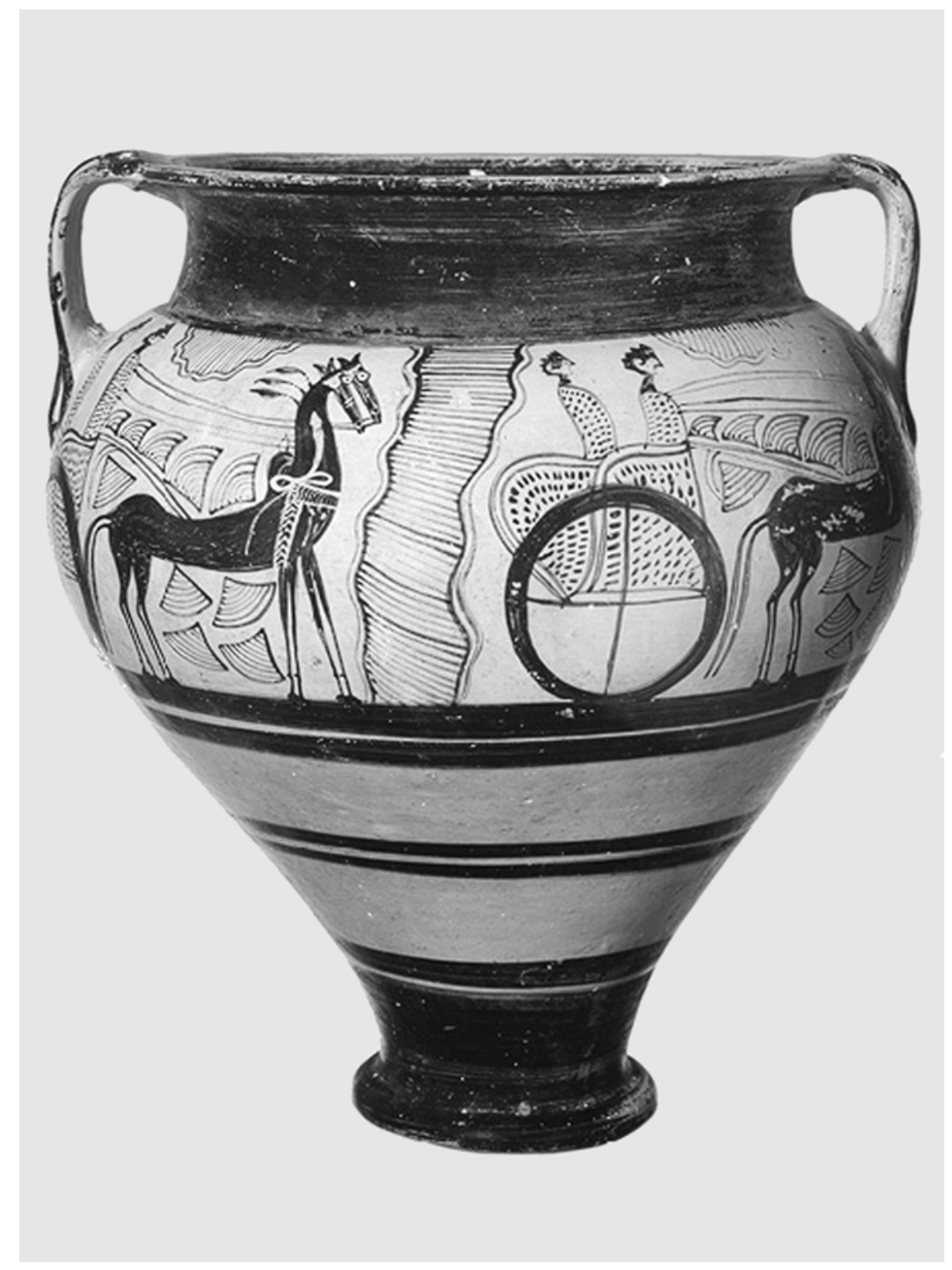

Figura 2. Representación de un carro en una crátera micénica.

Aunque no hay demasiados testimonios, también parece que en época micénica el caballo se emplea para la monta y algunas representaciones iconográficas ya del s. XIV a.C. así lo atestiguarían (Worley, 1994: 9-11), pudiendo haber sido el origen de la caballería como tal en Grecia.

Después del final de los palacios micénicos la información se reduce bastante, y si bien es posible que la presencia de carros pueda haber disminuido o desaparecido en buena parte de Grecia, no es improbable que los jinetes armados puedan haberse mantenido, en parte por la mayor facilidad que su desarrollo podría haber tenido (Worley, 1994: 13-15). 


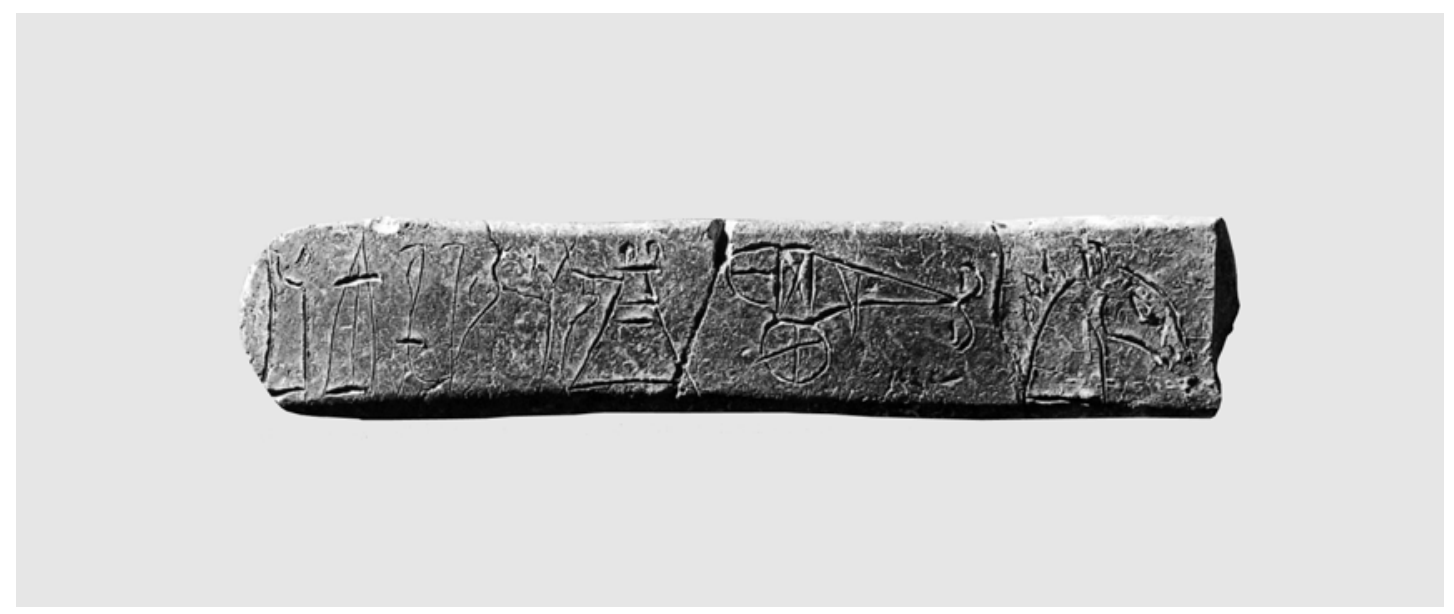

Figura 3. Tablilla KN Sc 230, mostrando el equipo militar asignado al guerrero o-pi-ri-mi-nijo: una coraza, un carro y un tiro de caballos.

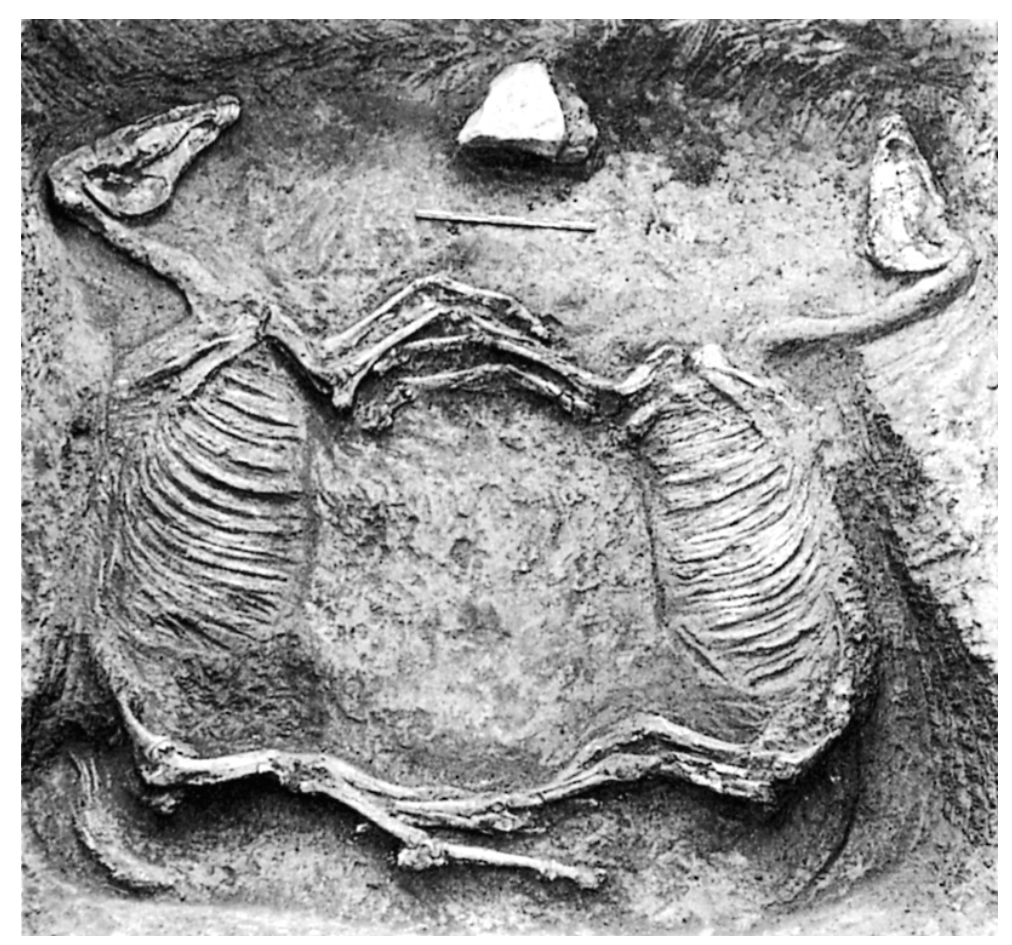

Figura 4. Caballos depositados en el dromos de acceso de una tumba micénica en Maratón.

\subsection{La época geométrica: entre carros y jinetes.}

Durante los llamados Siglos Obscuros el desarrollo de las diferentes partes de Grecia fue algo distinto, puesto que mientras que en algunas los niveles anteriores tardaron en recuperarse, en otras ya en el siglo X a.C., o antes, se observan rasgos evidentes de una recupera- 
ción económica y, sin duda, social. Uno de los casos más relevantes en este contexto nos viene dado por Lefkandí, en la isla de Eubea, donde ya para esos momentos parece formada una nueva aristocracia que mostrará, al parecer, una gran predilección por los caballos. Eso podemos observarlo, de forma muy palpable, en el llamado heroon de Lefkandí, una estructura de unos $40 \mathrm{~m}$. de longitud, en cuya parte central se habían producido los enterramientos de un hombre, los restos de cuya cremación se habían depositado en una crátera de bronce junto con sus armas (espada, lanza y piedra de afilar) y de una mujer con adornos y ornamentos de oro. Junto a la fosa que contenía esos cuerpos se excavó otra, de menor profundidad, en la que se depositó a cuatro caballos dos de los cuales aún llevaban bocados (Popham, Calligas y Sackett, 1993) (Figura 5). En el cementerio adyacente de Toumba se halló también otra tumba ( $\left.\mathrm{n}^{\circ} 68\right)$ que contenía dos caballos, asimismo con bocados (Popham, Calligas y Sackett, 1988-89: 118). Es posible que, como en sus precedentes de la Edad del Bronce, algunos individuos notables decidiesen enterrarse con los caballos que tiraban de sus carros como un medio de mantener o exhibir su rango más allá de la muerte. En el caso de la tumba principal, es destacable la aparición de cuatro caballos juntos, lo que sugeriría que el guerrero allí enterrado dispondría de una cuadriga, lo que resaltaría aún más el prestigio y el poder de que habría gozado en vida tal individuo. Se ha observado también en bastantes ocasiones cómo, con ocasión de los funerales del héroe Patroclo, que narra la Iliada, cuatro caballos fueron sacrificados en honor del difunto (Il., XXIII, 171-172). Por ende, las relaciones de los rituales funerarios que se observan en Lefkandí, así como en otras necrópolis Protogeométricas y Geométricas han sido también puestas de relieve en numerosas ocasiones.

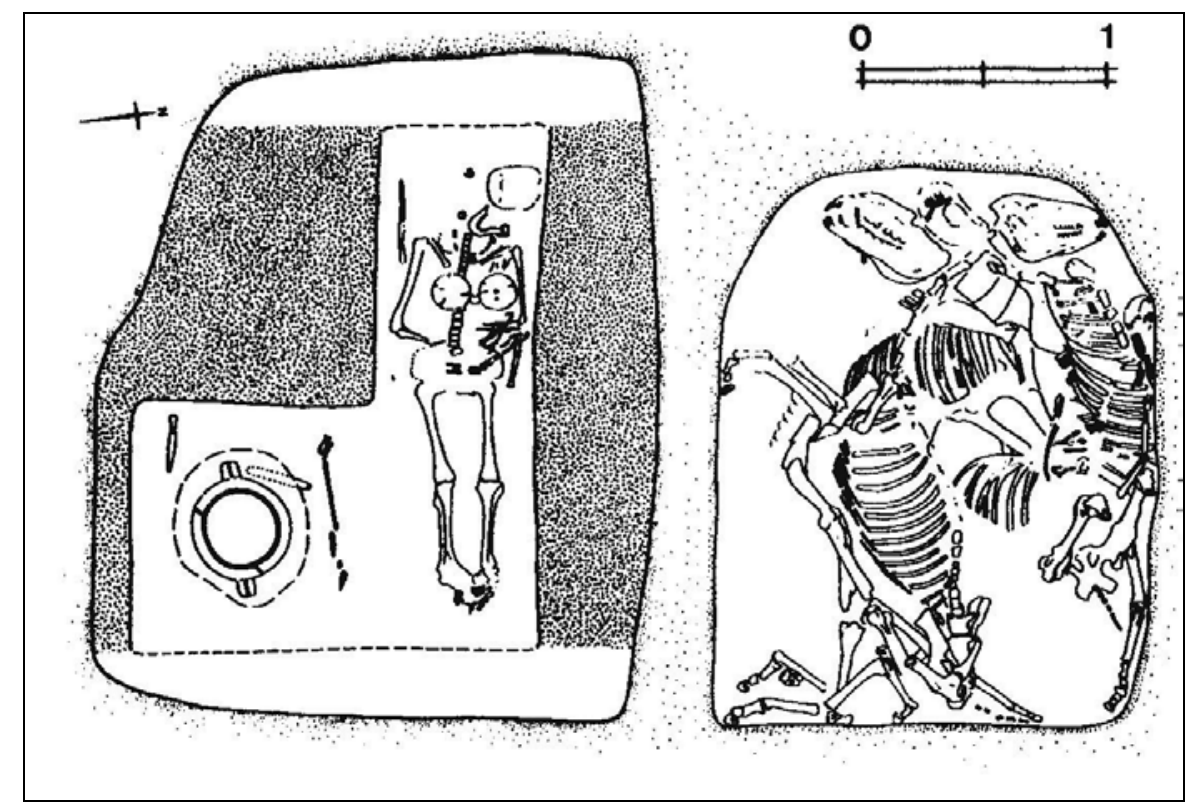

Figura 5. Los enterramientos y los caballos depositados en el heroon de Lefkandi.

Lo visto nos lleva, sobre todo a lo largo del Período Geométrico, a observar cómo de nuevo empezamos a tener informaciones de diversa índole sobre el empleo del caballo en este mundo griego que está poco a poco creando un nuevo marco político y cultural, que culminará en la aparición de la polis. Estas informaciones son de tres tipos principales, literarias, arqueológicas e iconográficas. 
Por lo que se refiere a las primeras, son los Poemas Homéricos quienes nos aportan datos valiosos sobre el uso del caballo en contextos bélicos aun cuando dicho uso no ha dejado de plantear problemas. A partir de las variadas descripciones de combates que nos muestra en especial la Iliada podemos observar cómo en ella el caballo actúa, como se ha dicho en muchas ocasiones, como un «taxi» que tan sólo transporta al guerrero al campo de batalla, desmontando acto seguido para combatir. Así lo podemos observar, por ejemplo, en la escena del combate entre Sarpedón y Patroclo; el primero, después de increpar a los licios que huyen ante el héroe aqueo decide ir a su encuentro «a ver si logro enterarme / de quién es éste que triunfa y es autor de tantos males, / pues a muchos troyanos valerosos ha postrado de rodillas. / Dijo, y del carro saltó a tierra con las armas. / Patroclo, al otro lado, nada más verlo, se apeó del carro» (Il., XVI, 419-427). Del mismo modo, y una vez acabado el combate el carro puede servir para arrastrar el cadáver del enemigo muerto, como hace Aquiles con el de Patroclo: «Le taladró por detrás los tendones de ambos pies / desde el tobillo al talón, enhebró correas de bovina piel / que ató a la caja del carro y dejó que la cabeza arrastrara. / Montó en la caja del carro, recogió la ilustre armadura, / los fustigó para arrearlos, y los dos de grado echaron a volar. / Gran polvareda se levantó del cadáver arrastrado; los cabellos / oscuros se esparcían, y la cabeza entera en el polvo / yacía, antes encantadora». (Il., XXII, 396-403). En cualquier caso, y derivando sin duda del marcado sabor aristocrático de los Poemas, en especial de la Iliada, pero también de los usos específicos del caballo en dicho poema, son abundantes las referencias al mundo de los caballos, incluso como término de comparación para las actitudes y comportamientos de los héroes principales del relato épico (Fagan, 2001).

Es difícil saber si el tipo de guerra que describen los Poemas Homéricos existió como tal en algún momento o estamos, más bien, ante una recreación por parte de los poetas de un mundo idealizado en el que conviven elementos de épocas diferentes que no quedan bien integrados en el discurso poético pero algunos paralelos, aunque lejanos, que remontan a la Edad del Bronce quizá sugieran la pervivencia de viejos modos de comportamiento (Beckman y Hoffner, 1999: 153-160; Güterbock, 1983: 134). Algunos autores, en su afán de racionalizar el relato, han llegado a sugerir que el carro no existía ya de hecho en la época post-micénica y, como mucho, aceptan que los guerreros acudían al combate montados a caballo, siendo el carro un añadido o embellecimiento propio del poeta (Greenhalgh, 1973: 61). Es seguro que en la tradición oral transmitida desde la época micénica, y que está en la base de los Poemas Homéricos, existían los carros porque como es bien sabido, los mismos debieron de desempeñar un papel importante en la guerra de la Edad del Bronce; sin embargo, el poeta no sabría cómo describir un combate en carro, algo que quizá no habría visto en su vida, por lo que el vehículo se convierte en medio de transporte, perdiendo en el poema el carácter militar que había tenido siglos atrás. Pero tampoco podemos perder de vista la observación de Anderson (1975: 175) en el sentido de que «no hubo un solo uso 'correcto' del carro de guerra en la antigüedad, del mismo modo que no hubo un solo uso 'correcto' de la caballería».

No obstante, esa imagen quizá no sea todo lo acertada que se piensa puesto que hay indicios arqueológicos y, sobre todo, iconográficos, del empleo del carro entre los siglos IX y VIII a.C. Estos indicios vienen de distintos puntos, pero podemos mencionar, por ejemplo, una tumba hallada en el ágora de Atenas (tumba XXVII), datable hacia el 900 a.C., en la que entre varias armas, espadas y lanzas sobre todo, se hallaron dos bocados de caballo, lo que sugiere que el aristócrata guerrero allí enterrado disponía de un tiro de caballos para tirar de su carro (Blegen, 1952: 279-294); a ello se pueden añadir otros numerosos testimonios que han sido recopilados en un reciente trabajo (Conter, 2003).

Por lo que se refiere a la iconografía, ésta nos presenta informaciones más precisas, a partir sobre todo de mediados del s. VIII a.C. Encontramos en la producción ateniense del llamado «Maestro del Dipilon» toda una serie de representaciones de escenas sobre todo de carácter funerario en las que es frecuente la aparición de carros bien para transportar a los 
difuntos bien realizando lo que pudieran ser procesiones en honor de los mismos. Del mismo modo, en alguna de esas grandes vasijas puede haber indicios de representaciones de escenas de guerra en las que intervienen individuos montados en carro, como en la crátera del Louvre A 519 (Langdon, 1993: 231-233; Snodgrass, 1998: 18-19). También de esos momentos datarían las primeras representaciones de guerreros montados a caballo, acompañando o desfilando con carros, como muestra el ánfora ática del Museo de Buffalo, en la que aparece un individuo armado con lanza y con una coraza de campana (Langdon, 1993: 60-64; Worley, 1994: 16-17). La práctica de la equitación, aunque no desconocida por completo en los Poemas Homéricos no es demasiado importante en los mismos.

Es también destacable el énfasis que, sobre todo en la segunda mitad del siglo VIII hacen las decoraciones cerámicas (Bouzek, 1959: 131-136; Langdon, 1993: 103-109, 210-211) como las figurillas de bronce en la representación de caballos, con frecuencia dedicadas en santuarios (Zimmermann, 1989), y que sugieren que es éste un momento de especial importancia para una nueva consideración de la función de este animal. Por si fuera poco, nuestras fuentes empiezan a referirse a determinados grupos aristocráticos con nombres relativos a la cría o a la monta de caballos. Sería, por ejemplo, el caso de los aristócratas de Cálcis, que serían llamados hippobotai (Hdt., V, 77, 2; Str. X, 1, 8), siendo los de Eretria conocidos como hippeis (Arist., Ath. Pol., 15. 2).

El descubrimiento en Argos, en 1953, de una tumba cuyo propietario se había enterrado con una coraza de campana, que se tiende a atribuir a un guerrero montado, así como la existencia de dos escifos procedentes de la misma tumba, decorados con caballos (Courbin, 1957: 322-386) puso sobre el tapete la realidad de guerreros a caballo en el último cuarto del siglo VIII a.C. (Worley, 1994: 17). El debate sobre la existencia de una auténtica caballería en Grecia, más allá de la existencia de jinetes, no es nuevo y ya en 1904 Helbig planteó que lo que había en el mundo griego más que caballería era una infantería montada que, en el momento del combate, desmontaría para combatir a pie (Helbig, 1904). Aunque el futuro, en buena parte de Grecia, iba a estar en la infantería pesada formada en falanges, en algunas poleis la existencia de la caballería como fuerza combatiente, pero también con importantes matices políticos y sociales, no puede perderse de vista. Aristóteles, buen observador de las realidades políticas lo deja claro cuando asegura que «aun entre los ciudadanos distinguidos se establecen diferencias según su riqueza y la magnitud de su hacienda, por ejemplo, por la cría de caballos; esto, en efecto, no pueden hacerlo con facilidad sino los ricos, y por eso en los tiempos antiguos todas las ciudades cuya fuerza consistía en caballería estaban gobernadas por oligarquías, y utilizaban los caballos en las guerras contra sus vecinos; así los eretrios y los calcidios y los magnesios de las orillas del Meandro» (Arist., Pol., 1289 b 33-40) y asegura, además, que los regímenes políticos más antiguos en Grecia tras la caída de las monarquías residían sobre los caballeros a cuenta de su superioridad en la guerra antes del desarrollo de la infantería (Arist., Pol., 1297 b 16.24). Cuestión diferente es cómo se empleaba la caballería en esos momentos si como una fuerza de choque o, por el contrario, se utilizaba el caballo como un medio de transporte para acceder al campo de batalla y, una vez en él, combatir a pie. Da toda la impresión de que durante el s. VIII esta última es la solución correcta, aunque no puede descartarse que los caballeros hayan actuado como una fuerza mixta que podía combatir tanto a caballo como a pie, según las circunstancias del combate (Worley, 1994: 23-26).

No obstante, en otras regiones de Grecia, con acusados rasgos arcaizantes habida cuenta su lejanía del núcleo principal de esta civilización, como puede ser Chipre, el caballo, en especial como elemento de tiro de carros de guerra sigue estando vinculado a los círculos de poder como muestran los hallazgos de la llamada «Necrópolis Real» de Salamina de Chipre; en varias de las tumbas excavadas, en especial en sus corredores de acceso, se depositaron carros junto con los caballos del tiro, tanto unos como otros con sus adornos y atalajes más 
lujosos. Esta costumbre persistió durante los siglos VIII y VII a.C. y es harto probable que los carros fuesen empleados para conducir al difunto hasta la propia tumba, tras lo cual los caballos serían sacrificados y dispuestos a la entrada de la misma. La costumbre también se atestigua en otras necrópolis chipriotas, aunque a escala más modesta (Karageorghis, 19671978; Rupp, 1988: 111-139).

\subsection{La época arcaica.}

\subsubsection{El paso del guerrero montado a la falange hoplítica.}

La época arcaica es la que ve el auge de la falange de infantes equipados con armamento pesado a los que conocemos como hoplitas. No cabe duda de que el apogeo de esta nueva forma de combate iba en detrimento de los caballeros que en muchas ciudades desaparecieron casi por completo o constituyeron unidades de tamaño y función casi irrelevante. No obstante, no ocurrió así en toda Grecia, y en algunos lugares, junto con las unidades de infantería, la caballería siguió teniendo cierta importancia. El pasaje de Aristóteles que mencionábamos antes relativo a Calcis y Eretria sugiere que las dos ciudades hacían un uso importante de la caballería, a tono con la denominación que se daban sus aristocracias dirigentes; el importante peso que la caballería tenía en Eretria lo sugiere una información de Estrabón (X, 1, 10) que indica que en el desfile que realizaban al santuario de Artemis Amarintia desplegaban tres mil hoplitas, seiscientos jinetes y sesenta carros. Una relación uno a cinco entre infantes y jinetes es bastante alta en Grecia y ello nos muestra el peso que, en época arcaica, tenía la caballería eretria. En la guerra que durante largo tiempo enfrentará a esta ciudad con su vecina Cálcis es posible que ésta haya tenido también caballería, pero la victoria decisiva habría sido consecuencia de la llegada de caballería tesalia en su apoyo, que habría derrotado a los jinetes eretrios (Plu., Mor., 760 E-F). De ser esto cierto cabe preguntarse si la caballería eretria actuaba tan solo como una infantería montada o, por el contrario, hacía labores propias de una caballería de combate hasta el punto que sólo su enfrentamiento con los tesalios, que tal vez ya desde épocas antiguas habrían desarrollado una verdadera caballería, propiciaría su derrota (Parker, 1997: 108-116).

Es, sin embargo, casi un axioma que la caballería era ineficaz en la práctica contra una formación hoplítica organizada aunque su uso podría verse aconsejado en determinados momentos del combate o con fines concretos dentro del mismo; por ejemplo, una formación de caballería podría atacar de flanco o por la retaguardia a la falange, en las áreas menos protegidas y, por consiguiente, donde podía causar más daño (Greenhalgh, 1973: 78-80). Del mismo modo, estaba también indicada para perseguir a los huidos en caso de colapso de la formación.

La importancia de Tesalia como uno de los territorios en los que se desarrolló bastante temprano una auténtica caballería ha sido resaltada en bastantes ocasiones; con una fuerza teórica de 6.000 jinetes frente a 10.000 infantes y numerosas tropas ligeras, Tesalia fue el prototipo de un territorio griego volcado de forma prioritaria en la caballería; además, desarrollaron formaciones específicas para sacar partido de esa fuerza (Worley, 1994: 29-32).

En el resto de Grecia, el siglo VII es la época del desarrollo de la falange hoplítica; como ha insistido en varias ocasiones Hanson «en los siglos VII y VI, los combates decisivos que pusieron fin a las disputas entre las ciudades-estado nacientes fueron llevados a cabo, en su mayor parte, por una infantería pesada compuesta por granjeros con armaduras de bronce y provistos de lanzas» (Hanson, 1999: 50). El papel de la caballería va disminuyendo a favor de esa nueva forma de combatir que gana adeptos en Grecia y que responde mejor a la nueva ideología (en teoría) igualitaria que la polis promueve; no obstante, no deja de haber caballe- 
ría en las ciudades griegas, como también muestra la iconografía que presenta abundantes representaciones de jinetes, a veces junto a infantes pesados. Aunque estos jinetes pudiesen, si era necesario, combatir a pie, si observamos los relieves del templo A de Prinias del último cuarto del s. VII veremos cómo los mismos se nos presentan armados con un escudo redondo y blandiendo una lanza, quizá en posición de ataque (Pernier, 1934: 171-177) (Figura 6). Así pues, y sin minimizar el papel de la falange de infantería pesada en la guerra arcaica, la caballería seguía teniendo su hueco en Grecia en estos momentos, siendo usada con mayor o menor intensidad según los casos y las propias tradiciones de cada ciudad, tanto contra soldados de infantería como contra otras formaciones de caballería (Worley, 1994: 35-48).

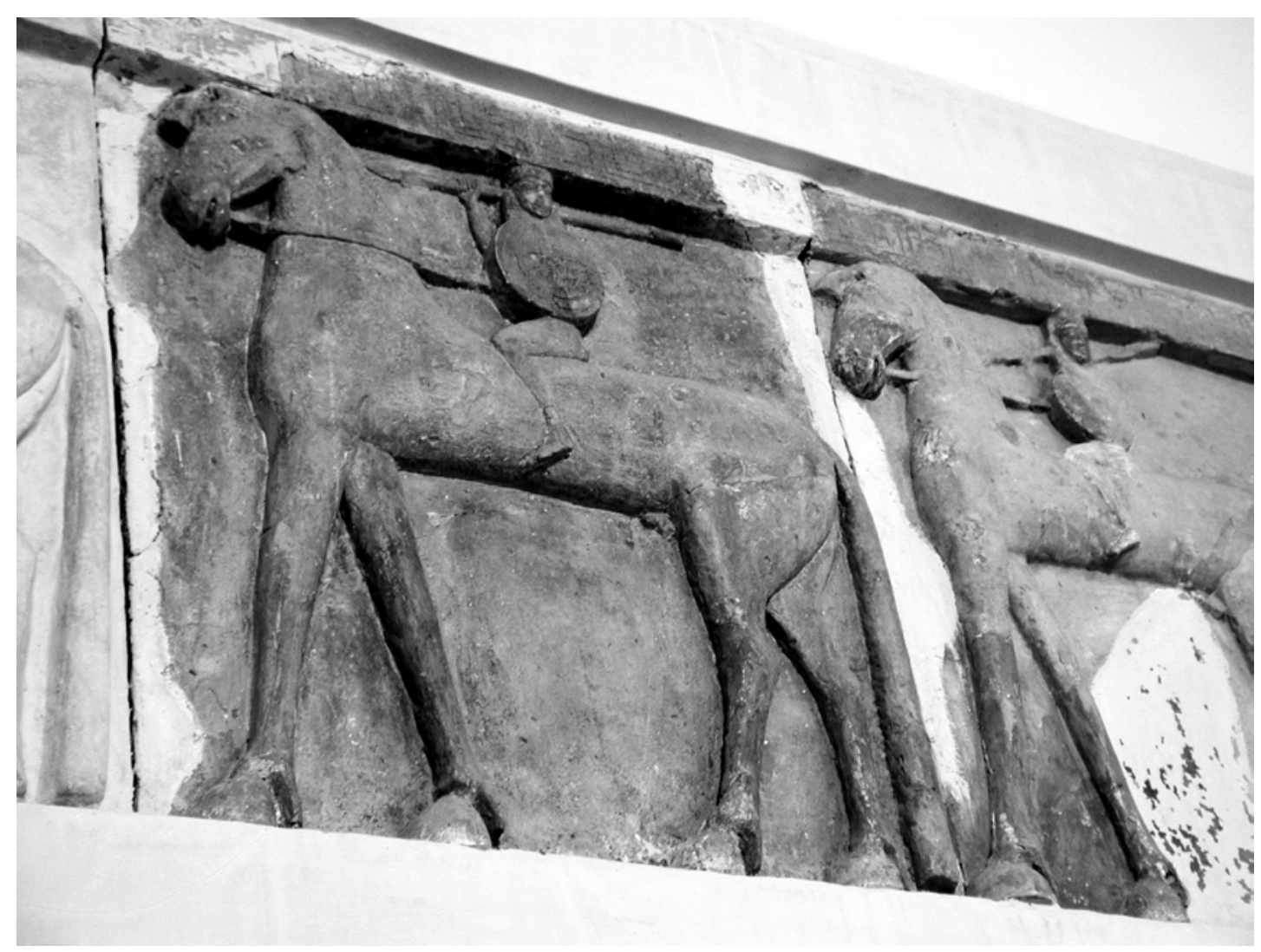

Figura 6. Friso de jinetes del templo A de Prinias.

Como ya habíamos visto en el pasaje de Aristóteles que mencionábamos antes, la posesión y uso de caballos no estaba al alcance de cualquier individuo, sino de aquellos que gozaban de un nivel económico suficiente y de tierras algo que durante buena parte al menos del arcaísmo estaba reservado a los aristócratas. Eso queda claro, por ejemplo, en Atenas donde Solón reserva las principales responsabilidades del estado al grupo social de los caballeros o hippeis, que habrían existido ya con anterioridad y del que, tal vez, desgajase a los más ricos de entre ellos creando a los que denominó pentacosiomedimnos (Domínguez, 2001: 58-59).

Es sobre todo el marcado carácter aristocrático de los caballeros arcaicos lo que determinará que, frente a su no demasiado brillante uso en el campo de batalla, aquellos encuentren un modo de exhibir sus yeguadas y sus destrezas en otro terreno, a saber el deportivo. 


\subsubsection{Las competiciones deportivas que emplean caballos y otros équidos.}

De entre las diferentes pruebas que fueron conformando el repertorio a desarrollar en las competiciones atléticas, las que tuvieron como protagonistas a los caballos fueron las más apreciadas. Ya en los funerales que Aquiles organiza en honor a Patroclo juega un papel relevante la carrera de carros, que ganará Diomedes no sin dificultades (Il., XXIII, 262-645), aunque habrá otras pruebas (pugilato, lucha, carrera de velocidad, duelo con armas, lanzamiento de peso, lanzamiento de flechas y lanzamiento de jabalina) (Il., XXIII, 651-897). Del mismo modo, en la tradición de la fundación de los Juegos Olímpicos figura una carrera de carros, en la que Pélope compite por Hipodamía con el propio padre de ésta Enómao a cambio de su vida (Apolodoro, Epit., 2, 4-9). No obstante, en los más antiguos Juegos Olímpicos no hay datos directos sobre la existencia de carreras de carros, aun cuando los exvotos y los datos que sugieren que en el Peloponeso occidental los caballos y los carros tenían gran importancia parecerían contradecir este hecho. No obstante, las tradiciones más antiguas sobre estas competiciones no están exentas de sospecha, por lo que no siempre lo transmitido tiene por qué corresponder a la realidad.

Habrá que esperar, sin embargo, al siglo VII para tener informaciones más precisas; así, en efecto, a partir de la $25^{\mathrm{a}}$ Olimpiada (680 a.C.) se introduciría la carrera de cuadrigas (tethrippon) mientras que la carrera de caballos o keles lo haría en la $33^{\text {a }}$ (648 a.C.). El primer vencedor de este tipo de carreras, y no debe sorprender, sería un tesalio, Crauxidas de Cranón (Paus., V, 8.8) y en los poetas encontramos pronto los ecos de esas competiciones. Así, por ejemplo, Alcmán compara a varias jóvenes espartanas que compiten en la carrera con caballos de carreras Enéticos, Ibenos o Colaxenos (Alcmán, Frag. 1, vv. 50-59), lo que muestra ya la existencia de razas especializadas en la carrera en el s. VII a.C. Poco a poco, la carrera de caballos fue introduciéndose en los demás juegos panhelénicos, en su mayor parte durante el s. VI a.C., y también Atenas parece haberla incluido también en ese momento en sus reorganizadas fiestas Panateneas. Las carreras de caballos gozaron de gran popularidad en esos momentos y en Atenas surgió, durante la primera mitad del s. VI, una producción de ánforas que representaba, en cada cara, la cabeza en perfil de un caballo, habiéndose sugerido que podrían haber sido premios para las carreras de carros (Hemingway, 2004: 116-118; Birchall, 1972: 46-63) (Figura 7) y son bastante numerosos los testimonios de otro tipo, en especial escultóricos, que aluden a estas celebraciones hípicas en la ciudad de Atenas (Camp, 1998: 27-30).

De todas las pruebas hípicas, empero, la más popular desde su introducción, como decíamos, en la $25^{\mathrm{a}}$ Olimpiada siguió siendo la carrera de cuadrigas, que estaba reservada, sin duda, tan sólo a individuos de alto poder adquisitivo. Era una carrera de alto riesgo y en la misma se valoraba tanto la destreza del propio auriga cuanto la buena crianza de los caballos, cuyos dueños podían ser también mujeres; vencer en ellas proporcionaba elevado honor y fama, en especial en la ciudad de origen y relevantes personajes políticos usaban ese medio para incrementar su fama, como hicieron los tiranos siracusanos de los años iniciales del s. V o, incluso, Alcibiades ya en la última parte del mismo siglo (Vanhove et al., 1992: 114-118). Durante un corto periodo de poco más de cincuenta años se celebra en los Juegos Olímpicos una carrera de carros tirados por mulas o apene, que tenía gran popularidad en Occidente. En las monedas de algunas ciudades occidentales (Siracusa, Mesene) han quedado huellas de estas carreras y de las victorias ganadas con frecuencia por sus gobernantes. Del mismo modo, algunos restos escultóricos notables, como el conocido auriga de Delfos corresponden a monumentos erigidos en los santuarios panhelénicos para conmemorar victorias en carreras de carros (Chamoux, 1955).

Por otro lado, en ciudades como Atenas conocemos restos de bastantes monumentos ecuestres que honran a aristócratas atenienses que, representando a jinetes y a caballos, acaso 
hubiesen resultado vencedores en diferentes competiciones atléticas aun cuando pueden también estar mostrando a aristócratas que se representan, de forma bastante natural, como jinetes (Figura 8). Mostrando sus peculiaridades también en este caso, las mujeres espartanas, al menos de rango aristocrático, recibían instrucción en la monta de caballos, en la conducción de vehículos tirados por este animal y participaban también en competiciones ecuestres (Pomeroy, 2002: 19-24).

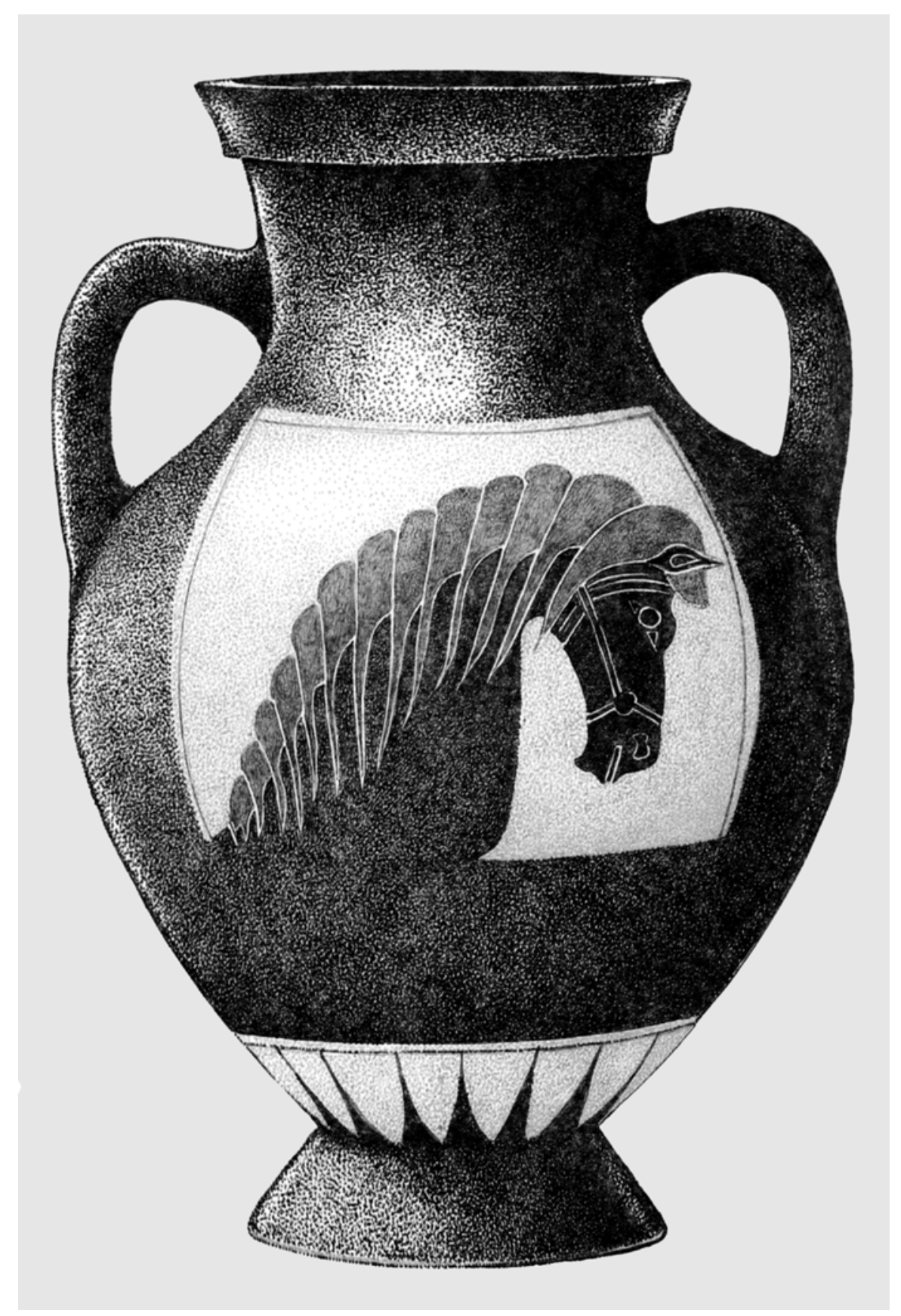

Figura 7. Ánfora de caballo, producción ática del s. VI a.C. 
Como han subrayado algunos autores, las competiciones atléticas hípicas no parecen haber tenido un especial sentido militar sino que serían competiciones agonísticas (Hemingway, 2004: 125-126), pero la importancia política y social de tales victorias era tan grande que algunos individuos, todavía en plena época clásica, seguían enterrándose con sus caballos como habían hecho sus antepasados de siglos atrás. Es el caso, por ejemplo, del ateniense Cimón el Viejo, que murió asesinado a fines del s. VI, y frente a cuya tumba «se hallan enterradas esas yeguas que triunfaron tres veces en los Juegos Olímpicos» (Hdt., VI, 103, 3-4).

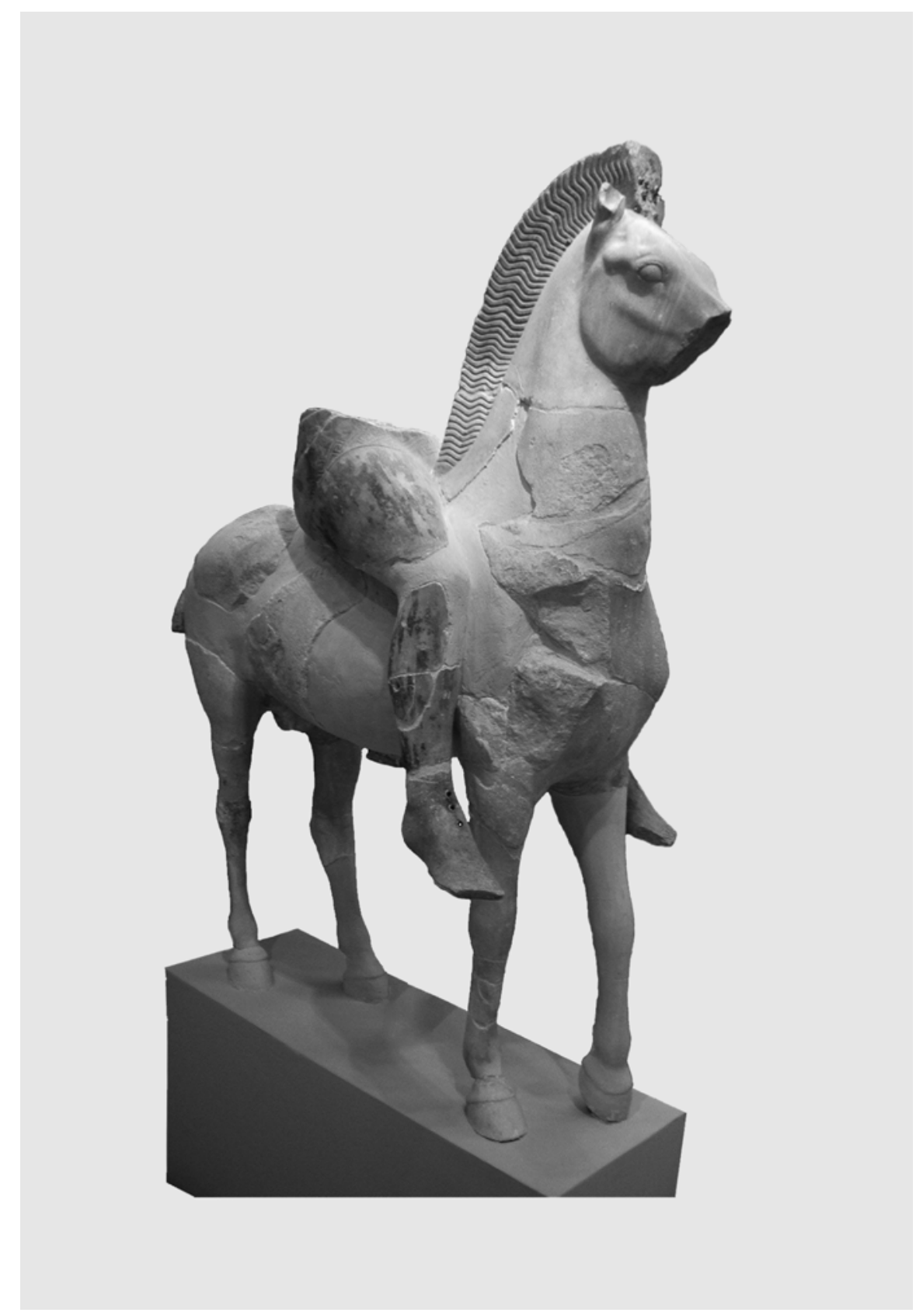

Figura 8. Ofrenda escultórica de un jinete en la acrópolis de Atenas. 


\subsection{La época clásica. El progresivo empleo de la caballería como arma de guerra.}

Después de este pequeño excurso sobre el uso deportivo del caballo en Grecia, volvamos a su uso en la guerra durante la época clásica.

\subsubsection{La experiencia de las Guerras Médicas.}

Durante las Guerras Médicas que enfrentan a los griegos con un estado como el persa que, heredero de una larguísima tradición oriental, hace un gran uso de la caballería, se hacen patentes las carencias de los griegos, o al menos de parte de ellos, en este campo. En efecto, en la batalla de Maratón los persas disponían de caballería, en una cantidad no precisada, pero quizá oscilando entre los 800 y 1.000 jinetes (Hammond, 1968: 13-57; Domínguez, 1999: 257-267), pero los atenienses y sus aliados no, como asegura el propio Heródoto (VI, 112, 2) al narrar el combate. No obstante, en las informaciones que poseemos sobre el desarrollo de la batalla la caballería persa permanece ausente, al menos durante buena parte de la misma, habiendo sido objeto de especulación qué pudo haber motivado la ausencia de esa importante arma durante el enfrentamiento o, al menos, en parte del mismo. El hecho de que la derrota persa determinase su repliegue inmediato hizo que, en este momento al menos, los griegos del continente no apreciasen en todos sus extremos lo decisiva que podía resultar la caballería en manos de sus enemigos.

En el siguiente gran enfrentamiento terrestre, en Platea, en el 479 a.C., ya en los momentos previos se observa cómo los escuadrones de caballería persas ponen en serio riesgo la posición griega al pie del Citerón con sus ataques en oleadas sucesivas (Hdt., IX, 20-21). También en estos prolegómenos se nos informa de que Atenas disponía ya de un cuerpo de arqueros (Hdt., IX, 22, 1), que había intervenido poco antes en la batalla de Salamina (Esquilo, Persas, 460; Plut., Temistocles, 14), aunque la coalición griega reunida allí (cifrada por Heródoto, IX, 29 en treinta y ocho mil setecientos hoplitas y en sesenta y nueve mil infantes ligeros) seguía siendo deficitaria en caballería ( $c f$. Hdt., IX, 54; 60). Precisamente, los persas contaban entre sus aliados en dicha batalla a griegos que descollaban en el uso de la caballería, como los tebanos, los tesalios y los macedonios (Hdt., IX, 40; IX, 45-46). El día previo a la batalla la caballería persa causa bajas e incertidumbre entre los griegos con sus ataques en oleadas, en las que lanzaban flechas, impidiéndoles ademas abastecerse de agua y su dominio del terreno impedía que los abastecimientos griegos llegasen hasta el ejército (Hdt., IX, 49-50). La superioridad persa en caballería se ve patente al inicio de la batalla puesto que toda ella en masa ataca a los espartanos que solicitan auxilio a los atenienses o, en todo caso, que éstos les envíen los arqueros (Hdt., IX, $60,3)$; no obstante, la resistencia de la falange espartana les permite avanzar contra los arqueros y la caballería persas y, por fin, dar muerte a Mardonio y obtener la victoria (Hdt., IX, 62-63). En la retirada persa, la caballería beocia siguió ejerciendo su función protectora evitando que los perseguidores dieran alcance a los derrotados (Hdt., IX, 68). Aunque de nuevo había quedado clara la capacidad de la falange hoplítica, en especial si iba apoyada por arqueros, para resistir a ataques directos de la caballería (Worley, 1994: 54-56), también era evidente la capacidad de la caballería para entorpecer los movimientos de la infantería y dificultar la acción de un ejército que no dispusiese, a su vez, de este recurso bélico. Los atenienses aprenderían la lección, aunque en uno de los momentos decisivos volverían a descuidar su uso, en especial en su lucha contra Siracusa dentro de la Guerra del Peloponeso.

\subsubsection{Los tiranos de Sicilia.}

La mención de Siracusa nos lleva a un ámbito distinto, cual es el siciliano, en el que la caballería también jugará un papel importante. Desde el inicio de la presencia griega en la 
isla los caballos jugarán un papel importante en el desarrollo de las aristocracias que dirigían las ciudades; la existencia de amplias llanuras y de importante recursos económicos, así como de regímenes aristocráticos que se beneficiaban de ellos determinaron un temprano desarrollo de la caballería en la isla. No obstante, cuando empezamos a percibir el gran peso que la caballería tiene en Sicilia es a partir del surgimiento de la tiranía en Gela y su traslado ulterior a Siracusa. Un primer indicio del peso que la caballería tenía a fines del s. VI en la ciudad de Gela es que el tirano Hipócrates designará para el cargo de hiparco a Gelón a causa de su valía (Hdt., VII, 154, 2). A la muerte del tirano, Gelón acabará asumiendo el poder y hacia el 481 recibe una embajada de griegos del continente que le solicitan ayuda en la inminente guerra contra los persas. El tirano puede ofrecer, entre otros contingentes, dos mil jinetes y otros dos mil soldados de caballería ligera (Hdt., VII, 158, 4) que al final no entrarán en combate contra los persas, aunque tal vez formarán parte del contingente de cinco mil jinetes que el propio Gelón conduce hasta Hímera para luchar contra los Cartagineses y que ya antes de la batalla causa importantes bajas a los enemigos (Diod., XI, 21, 1-2), jugando un papel importante, al decir de Diodoro (XI, 21, 5; XI, 22,1) en el inicio de la batalla y en el éxito de la misma al provocar la muerte del general cartaginés Amílcar.

\subsubsection{Las guerras del s. V, en especial la Guerra del Peloponeso}

Atenas percibió cómo la superioridad en caballería de sus enemigos los persas, pero también de otros griegos, como los beocios, con quienes se habían enfrentado en la batalla de Platea era un grave inconveniente para desarrollar la política de dominio que su victoria les garantizó y la ciudad tomó interesantes medidas para dotarse de una fuerza móvil y versátil que, montada a caballo, les garantizase, al menos, un equilibrio de fuerzas en el campo de batalla, aun cuando a juzgar por las cifras que da Heródoto (VII, 87) para la caballería persa que atacó Grecia (80.000 jinetes) difícilmente podrían los griegos llegar a tal equilibrio. No obstante, frente a su vecina y rival Beocia, que a principios del s. IV disponía de una fuerza de 1.100 jinetes, semejante a la que podía reclutar ya en el s. V (Pascual, 1997: 57-58), Atenas sí podía hacer un esfuerzo, y lo hizo.

Sus primeros pasos fueron reclutar un contingente de trescientos jinetes así como contratar los servicios de otros trescientos arqueros escitas (Andoc., 3, 5), tal vez después de la batalla de Tanagra (457 a.C.) en la que los mil jinetes tesalios que eran aliados de Atenas se pasaron a los espartanos en mitad del combate (Tuc., I, 107-108). No obstante, enfrentamientos en los años siguientes demostraron que esa fuerza seguía siendo insuficiente y su número se elevó a 600 y, años antes del inicio de la guerra del Peloponeso a 1000 jinetes y 200 arqueros a caballo (Spence, 1993: 15-16; Worley, 1994: 70-71). Esto se logró mediante una política de préstamos (de hasta 1.200 dracmas) a quienes quisieran formar parte de la caballería para poder comprar el caballo, así como subvenciones para su manutención, que suponían un fuerte desembolso para la polis, que Jenofonte (Hipparch., 1, 19), excelente conocedor del tema cifraba en cuarenta talentos (240.000 dracmas) al año (Spence, 1993: 272-276); por supuesto, la polis se reservaba el derecho de controlar e inspeccionar el buen estado de los caballos así como su valor económico, tal y como muestran algunos autores antiguos (por ejemplo, Aristóteles, Ath. Pol., 49) y diversos documentos epigráficos hallados en la propia Atenas (Kroll, 1977: 63-140).

La nueva caballería ateniense es representada en el friso del Partenón participando en una cabalgata en relación con la fiesta de las Panateneas, y mostraría el orgullo de la ciudad ante la creciente importancia de esa unidad dentro del diseño militar de Atenas, por más que las interpretaciones del friso sean variadas en cuanto al sentido último del mismo (Jenkins, 1994; Neils, 2001; $c f$. Spence, 1993: 262-271) (Figura 9). La caballería ateniense intervino en 
diferentes ocasiones durante la Guerra del Peloponeso, incluyendo una de las más graves derrotas que sufrió Atenas a lo largo de su historia, en la expedición a Sicilia (MacInnes, 1991: 193-195; Worley, 1994: 83-122). No obstante, fue el poco número de efectivos que en un primer momento enviaron los atenienses así como las dificultades para mantener un buen nivel de servicio las que determinaron que la caballería siciliana acabase haciendo difícil para los atenienses la campaña. El propio Nicias, en su segundo discurso ante la asamblea ateniense plantea como uno de los principales riesgos de la expedición a Sicilia la superioridad en caballería de Siracusa y la necesidad para Atenas, por consiguiente, de conseguir aliados en la isla que les proporcionen caballería (Tuc., VI, 20,4-21,1). No obstante, el primer ejército expedicionario ateniense que parte para Sicilia consta tan sólo de 30 caballos y sus jinetes, aunque Atenas sí llevaba un importante número de tropas ligeras, en especial arqueros (cuatrocientos ochenta) y honderos (setecientos) (Tuc., VI, 43); el ejército siracusano que se despliega en el Olimpieio de la ciudad para hacer frente a Atenas constaba, entre otras tropas, de mil doscientos jinetes (Tuc., VI, 68, 2), con lo que la desproporción era evidente y se ajustaba a lo que el siracusano Atenágoras había vaticinado en la asamblea de su ciudad cuando pronosticó que los atenienses no llevarían caballos y que apenas se los podrían procurar en la isla (Tuc., VI, 37, 1). Estos jinetes permitieron a los infantes siracusanos una segura retirada a su ciudad después de haber sido derrotados por los atenienses (Tuc., VI, 70, 3).

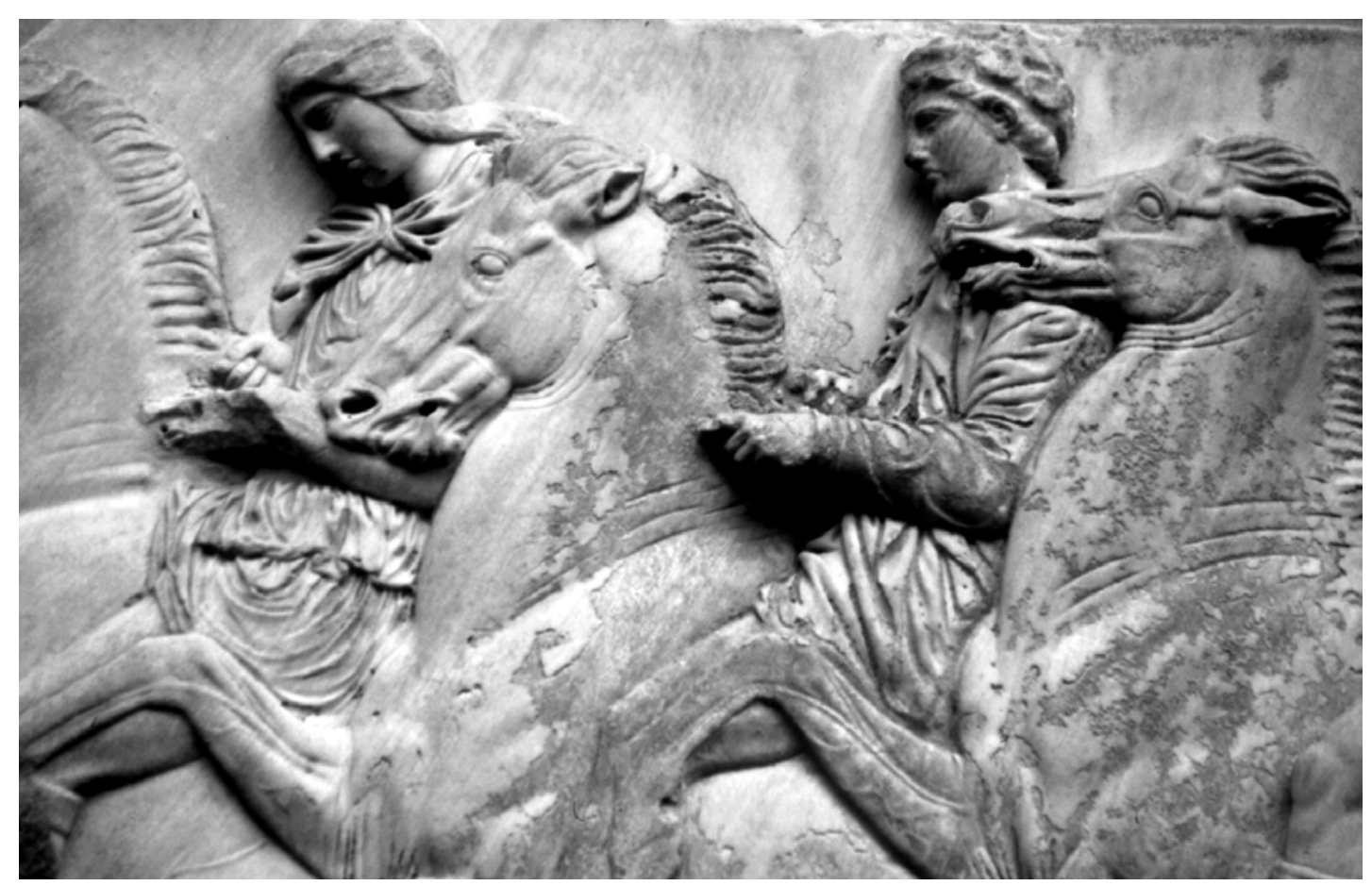

Figura 9. Friso del Partenón mostrando la procesión de los jinetes.

Aunque de nuevo había quedado clara la superioridad de una falange en formación frente a la caballería, la fuerza expedicionaria ateniense no podía desarrollar por completo sus capacidades sin disponer de una caballería eficaz, que fue en su momento solicitada a Atenas (Tuc., VI, 72, 2; 93, 4). Atenas acabó comprendiendo esas necesidades cuando en el 414 envía como refuerzos doscientos cincuenta jinetes y treinta arqueros a caballo, aunque aqué- 
llos no iban con sus caballos sino que esperaban poder procurárselos en la propia isla (Tuc., VI, 94, 4). De hecho, entre estos caballos que consiguieron y las fuerzas de otros aliados Atenas pudo reunir un contingente de entre 650 (Tuc., VI, 98, 1) y 800 (Diod., XIII, 7, 4) jinetes, que era ya una cifra razonable aunque inferior a la que sus enemigos poseían. En las operaciones que se sucedieron la capacidad de hostigar de la caballería siracusana se demostró muy superior a la de la caballería ateniense de contrarrestar sus efectos, como el propio Nicias reconoce en una carta enviada a Atenas al final del verano del 414 a.C. (Tuc., VII, 11, 4); la última noticia que Tucídides conserva de la caballería ateniense en Sicilia se refiere a la captura por los siracusanos de setenta caballos que fueron dejados atrás por sus jinetes que desmontaron para poder refugiarse tras los muros atenienses (Tuc., VII, 51, 2).

En la última parte de la campaña, durante la huida ateniense, la caballería siracusana y sus tropas ligeras van a hostigar de forma permanente a los atenienses obligándoles a llevar a cabo una marcha muy lenta y penosa hasta su derrota total (Tuc., VII, 78, 3-7; 81, 2; 84, 2). En la batalla decisiva en el río Asinaro, la caballería siracusana actúa de tal modo que impide la huida de los que han conseguido salir del lecho del río (Tuc., VII, 85, 1).

Si el inicio del siglo $\mathrm{V}$ había puesto de relieve las carencias de la caballería en buena parte de las poleis griegas, el siglo acababa con un renovado interés por esta arma, que aunque no era por lo habitual el factor decisivo en la victoria o la derrota de los ejércitos había demostrado su importancia a la hora de dificultar las tareas enemigas y se había convertido en un elemento cada vez más importante. Sería en el siglo siguiente cuando todas sus potencialidades se pondrían de manifiesto aunque, si hemos de referirnos a Atenas, la implicación de los caballeros a favor del régimen oligárquico de los Treinta Tiranos les restó durante bastante tiempo confianza entre sus conciudadanos (Spence, 1993: 216-217; Krentz, 1982: 64-65).

\subsubsection{El siglo IV, el momento de despegue de la caballería griega.}

A lo largo de este siglo IV la caballería pasará a ser un elemento integrado por completo en la disposición de los ejércitos, y no algo marginal a ellos. Es también el momento en el que indudables autoridades en la materia, como Jenofonte, aúnan su experiencia militar directa con una importante labor teórica.

Jenofonte, sin duda uno de los caballeros que había apoyado al gobierno de los Treinta en Atenas, formó parte del ejército mercenario que el pretendiente al trono persa, Ciro, había reclutado para oponerse a su hermano el rey Artajerjes II. Es tras su derrota en Cunaxa y el inicio de su retirada y la muerte de los generales griegos cuando Jenofonte es elegido por el ejército como uno de sus nuevos generales. La superioridad en la caballería persa era evidente y eso puso en graves aprietos a los griegos, hasta que Jenofonte propuso organizar un cuerpo de honderos rodios, de entre los soldados del ejército y un primer cuerpo de caballería compuesto de cincuenta jinetes, usando aquellos caballos que pudiesen ser de utilidad para la monta (Xen., Anab., III, 3, 15-20). Con un contingente tan poco numeroso se pudo, no obstante, mantener al ejército griego dentro de ciertos límites de seguridad.

Poco a poco se van introduciendo novedades, como la que favorece el rey espartano Agesilao en Jonia cuando, para obtener caballería, tan necesaria para combatir contra los persas, «a los ciudadanos más ricos de todas las ciudades de la zona los inscribió para que mantuvieran la caballería y proclamó que a quien proporcionara un caballo, armas y el hombre adecuado, le estaría permitido no participar en el ejército» (Xen., Hell., III, 4, 15); es posible que a Jenofonte se le confiase la instrucción de estas unidades (Worley, 1994: 136), que pronto obtuvieron importantes éxitos contra los persas cerca de Sardes (Xen., Hell., III, $4,23.24$ ) merced a la combinación de fuerzas que Agesilao hizo de infantería y caballería. 
En la batalla de Leuctra (371 a.C.) la caballería beocia logró rechazar a la caballería espartana, de peor calidad, que en su retirada desordenó las propias líneas espartanas y permitió el golpe fatal que el ala izquierda tebana les asestó (Xen., Hell., 6, 4, 13). Como observó Cawkwell (1972: 262), «la batalla mostró por vez primera en una batalla griega esa coordinación de armas que iba a ser desarrollada de forma tan extraordinaria por Filipo y Alejandro».

\subsubsection{Jenofonte, su experiencia militar y su labor teórica.}

Es Jenofonte, como apuntábamos antes, quien nos proporciona informaciones de gran valor acerca de cómo se debe dirigir una fuerza de caballería y sobre su funcionamiento en sus dos obras, el Hipparchikos y el Peri Hippikes; además de conocedor, Jenofonte era un gran amante de los caballos (L'Allier, 2004: 129-134). El tipo de caballería que propugna Jenofonte en la primera de ellas para su ciudad, Atenas, implica un adiestramiento continuo tanto para poder dominar al caballo sobre cualquier terreno como para practicar los diferentes tipos de aproximación al enemigo y hacerle el mayor daño posible. Asimismo, discute sobre los distintos tipos de formación e introduce la idea de que sería interesante disponer de al menos doscientos jinetes mercenarios que serían pagados mediante el mismo procedimiento que había empleado Agesilao en el 396 en Jonia. En la segunda de ellas, además de consideraciones acerca de la adquisición, limpieza y doma del caballo, insiste también en las protecciones que jinete y caballo deben llevar, entre ellas el peto y el casco de tipo beocio; como armas defensivas prefiere la machaira y dos jabalinas cortas de tipo persa de madera de cornejo; en definitiva, la información que nos proporciona Jenofonte resulta de un interés extraordinario para conocer en profundidad el mundo del caballo en la Grecia clásica (Anderson, 1961: 117-127).

\subsection{Las innovaciones macedonias.}

Con el inicio de la intervención de Filipo II en los asuntos de Grecia entramos en el último de los momentos en el desarrollo de la caballería griega, cuando se convierte, según la bien conocida metáfora, en el martillo que golpeará a los enemigos contra el yunque representado por la falange macedonia (Worley, 1994: 153; Moreno, 2004: 109-122). Filipo construyó un gran ejército, en el que la caballería iba a jugar un papel relevante; otorgando tierras a cambio del servicio como jinetes, el rey se atrajo a un nutrido grupo de macedonios, pero también a griegos de otras procedencias. Eso le permitió reunir un gran contingente que utilizó en sus diferentes campañas; así, en Queronea Filipo II disponía de dos mil jinetes (Diod., XVI, 85, 5) que no eran sino una parte de la caballería macedonia, mientras que Alejandro cruzó a Asia con cuatro mil quinientos jinetes, de los que mil ochocientos eran macedonios, otros tantos tesalios, seiscientos griegos y otros novecientos tracios y peonios (Diod., XVII, 17, 4).

El arma principal de la caballería macedonia era la sarissa de caballería, una lanza ligera de casi tres metros de longitud, y por lo habitual la caballería adoptaba una formación en cuña, que les facilitaba la penetración entre las líneas enemigas al cargar contra ellas. Estas dos circunstancias le permitieron a Alejandro, al frente de la caballería, romper la falange beocia en Queronea y aniquilar al batallón sagrado tebano (Plut., Alex., 9, 2). En las dos principales batallas contra los persas, Isos y Gaugamela, Alejandro consiguió introducir su caballería en las líneas enemigas provocando en ambos casos la huída del rey Darío y la victoria macedonia (Worley, 1994: 165-167). No obstante el uso verdaderamente innovador que Filipo y Alejandro hicieron de la caballería, la misma perdió importancia como masa de ma- 
niobra (Ducrey, 1985: 105), puesto que la infantería pesada se había convertido en la fuerza esencial en los escenarios bélicos.

\section{LOS ECOS EN IBERIA DEL USO DEL CABALLO EN GRECIA.}

Antes de entrar en este último apartado, querría hacer un par de consideraciones de principio. En primer lugar, mi intención aquí es tan sólo realizar algunas observaciones acerca de los (posibles) ecos que el mundo del caballo griego puede haber tenido en Iberia sin insistir en exceso en aspectos mucho más detallados que son objeto de estudio reciente por diferentes especialistas (Quesada y Zamora, 2003); en segundo lugar, hay que aclarar, por si hubiera alguna duda, que el uso del caballo en la Península Ibérica no parece relacionado con la presencia griega, sino que tiene un desarrollo autónomo y, en todo caso, influido también por los fenicios, como mostraría la presencia de bocados de caballo e, incluso de un carro, en la tumba 17 de la necrópolis onubense de La Joya (Garrido y Orta, 1978), cuyos prototipos se vinculan más al mundo fenicio y, por supuesto, las representaciones de carros de las llamadas estelas del suroeste (Celestino, 2001: 211-232; Quesada, 1997a: 157-164); todo ello sugiere, pues, que el mundo ibérico tuvo su propia aproximación al mundo del caballo, incluyendo además sus propios sistemas de cría, no bien conocidos, pero que quizá sigan patrones comunes a otros estudiados en diferentes ámbitos europeos (Sundkvist, 2004: 241-249).

Por consiguiente, podemos asegurar que los griegos no enseñaron los usos del caballo a los iberos, pero sí podemos decir que ya desde temprano la iconografía griega mostró a las poblaciones de Iberia los usos que al caballo daban los griegos. Así, ya desde los materiales griegos más antiguos que aparecen en Iberia, como la píxida o la crátera del Geométrico Medio II de Huelva la iconografía griega del caballo está presente en la Península; más adelante en el tiempo pueden mencionarse otras piezas, como el ánfora de cabeza de caballo de Huelva, la kylix de Medellín, una copa de los Pequeños Maestros de Málaga, una copa Droop del Cabezo del Tío Pío en Archena, la crátera de columnas de la Albufereta o la lécito del grupo de Haimon de Villaricos, entre los materiales más antiguos, por no mencionar la profusión de temas ecuestres en las cerámicas del s. IV a.C. (Domínguez y Sánchez, 2001).

Quiere esto decir que la Península Ibérica recibió desde muy pronto imágenes que tenían un sentido determinado en Grecia pero que por estar en un lenguaje comprensible a primera vista, como era el de las imágenes, podía recibir interpretaciones propias en el ambiente receptor.

Problema distinto presentan otras iconografías como las escultóricas. El complejísimo conjunto de Porcuna (González, 1987; Negueruela, 1990) presenta varias escenas de combate en la que el caballo adquiere una gran relevancia aunque su uso como elemento de transporte del guerrero más que como de combate ha sido argumentado de forma convincente (Quesada, 1997b: 185-194; Id., 1998: 172); las referencias al uso del caballo al servicio de la guerra en Iberia, no sólo iconográficas sino también literarias, no son tampoco raras pero son más abundantes y precisas cuanto más nos acercamos a la época romana y disponemos de más informaciones (Gracia, 2003) lo que siempre permite plantear cuánto de adaptación de tácticas bélicas foráneas puede haber llegado a las poblaciones indígenas de la Península y cuánto de original puede haber en ellas, cuestión que aquí no abordaremos.

No obstante y volviendo al conjunto de Porcuna, el caballo sirve para caracterizar a su poseedor que, aunque combata desmontado requiere de la representación del animal a su lado para denotar su estatus y su posición social y militar (Figura 10). Por ende, en el conjunto de Porcuna hay una gran ostentación de armamento y de violencia como corresponde a la narración de algún hecho que la comunidad responsable de su erección quiere recordar y aunque sin duda la historia que están contando esas esculturas y el sentido último de lo narrado sólo puede entenderse dentro del contexto de la sociedad ibérica que lo genera, el len- 
guaje formal e iconográfico no deja de estar influido por el mundo griego, donde también las artes plásticas sirven para conmemorar hechos del pasado. Otras escenas escultóricas, como el caballo de Casas de Juan Núñez, muestran una relación más que evidente con los modos de trabajar de los escultores formados en ambientes griegos, aun cuando no sea necesario postular para las mismas por fuerza artesanos de este origen (Faustoferri, 2000: 315-324) (Figura 11). El pilar-estela de Coimbra del Barranco Ancho, por su parte, con su escena de despedida, cuyos prototipos griegos han sido observados por diversos investigadores y con una procesión de tres jinetes, dos de ellos con ropajes «civiles» y un tercero tal vez armado, o realizando un gesto de lamentación (Muñoz, 1988: 229-255; García Cano, 1997: 263-272; Izquierdo, 2000: 100-104), tiene elementos de un simbolismo que nos resulta difícil de interpretar (uno de los caballos pisa una cabeza humana y un ave y otro un conejo) (Figura 12); la forma, el pilar-estela, tiene ya una larga tradición en el mundo ibérico para el momento en el que se erige el de Coimbra (mediados del s. IV a.C.) (Izquierdo, 2000: 422) y aunque no es habitual que en el pilar propiamente dicho haya decoración escultórica el de Coimbra experimenta con ese espacio e introduce los cuatro relieves. Como en otras ocasiones, la cultura ibérica se muestra plena de originalidad pero utiliza una idea, la procesión de jinetes, que tiene claros prototipos en el mundo griego, lo que es tanto más destacable cuanto que en la propia escena de despedida los paralelos más directos se han hallado en relieves griegos (García Cano, 1994: 173-201).

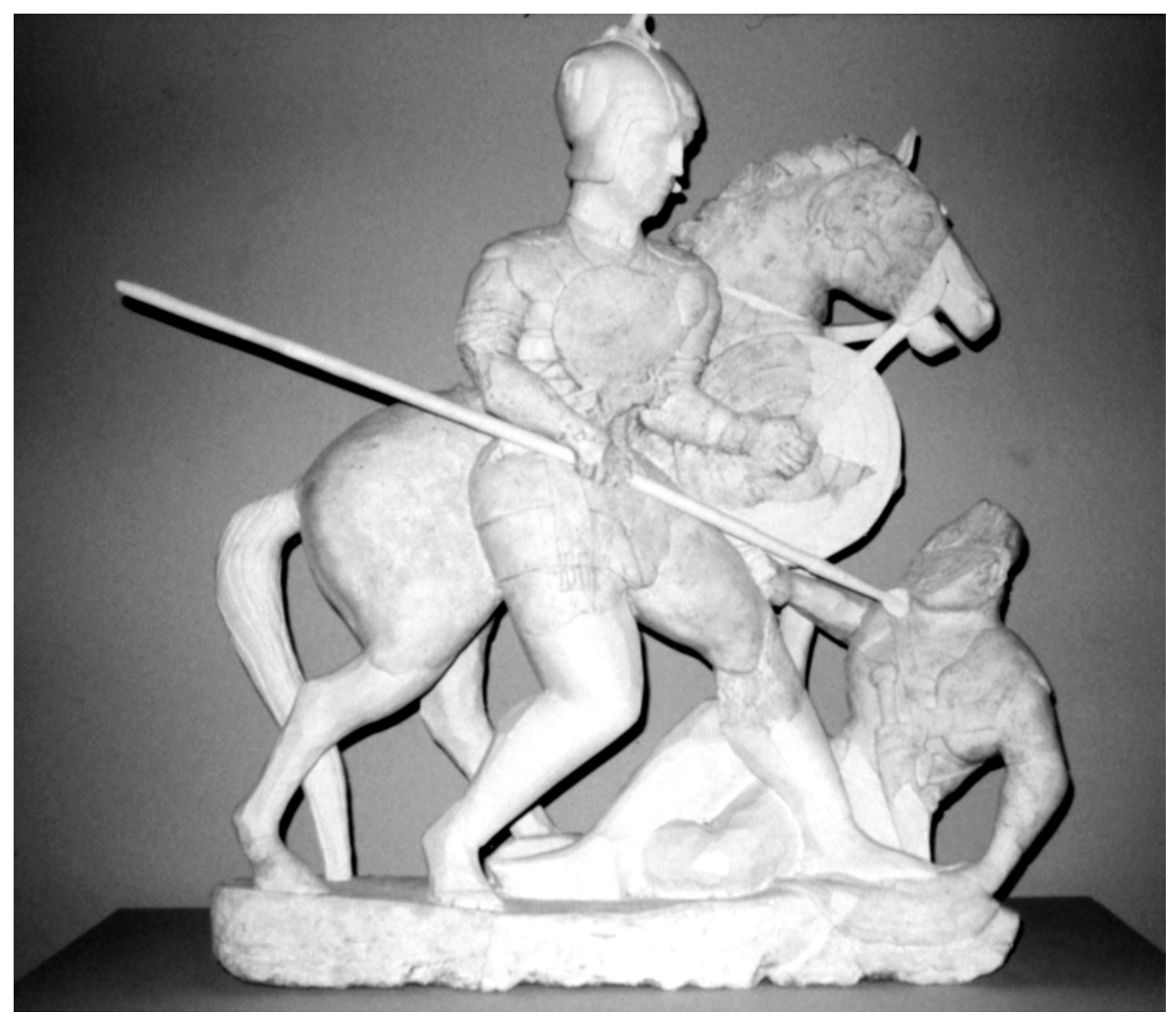

Figura 10. Escena de combate del conjunto escultórico del Cerrillo Blanco (Porcuna). 


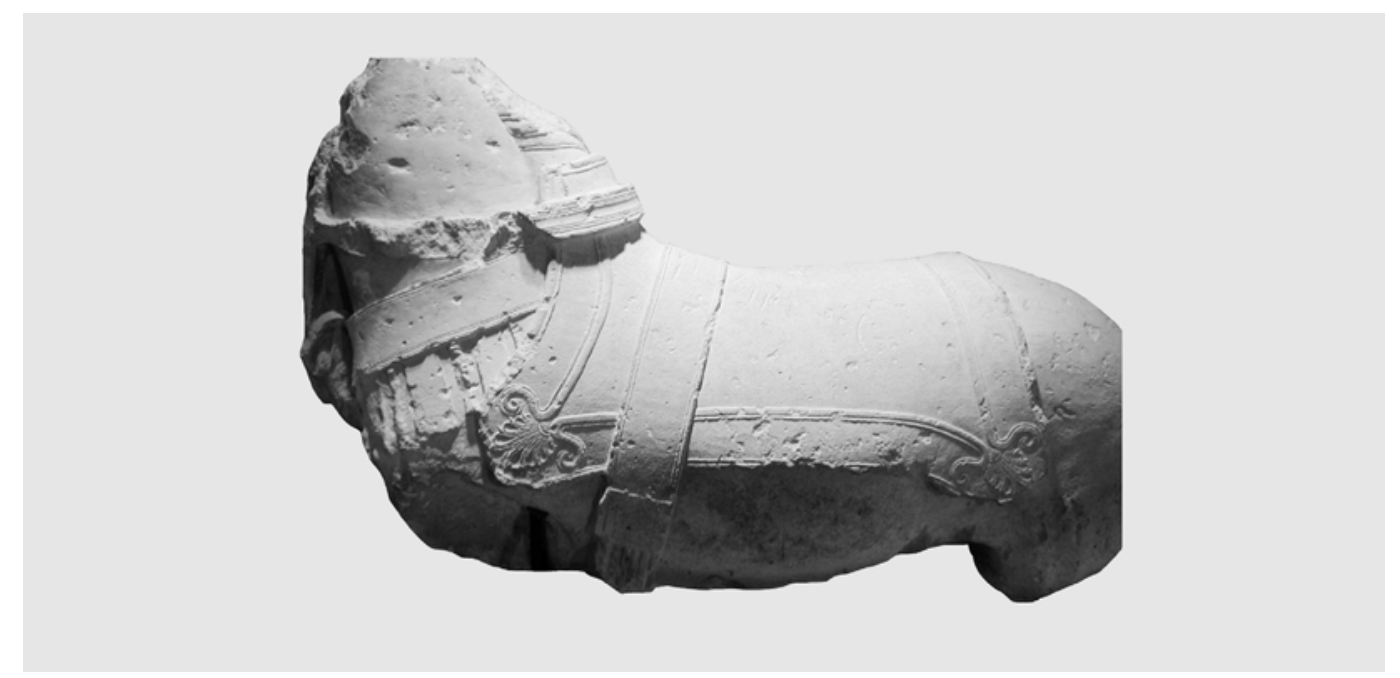

Figura 11. El caballo de Casas de Juan Núñez.

La vinculación del aristócrata a caballo con su tumba, que observamos en este monumento de Coimbra ya se había observado durante el siglo anterior, como muestran las dos esculturas ecuestres de la necrópolis de Los Villares. La más reciente, puede datarse entre los años finales del s. V y los inicios del s. IV a.C. y en ella se aprecia un jinete calzado con unas botas; la más antigua, datable en el $\mathrm{s}$. V presenta un jinete quizá vestido para el combate, pero sin armas (Blánquez, 1992: 121-143; Id., 1993: 111-128; Id., 1995: 238-245) (Figura 13). En ambos casos, las esculturas estaban sobre sendas tumbas como coronamiento de las mismas. Aunque la impresión de conjunto muestra que quienes han elaborado estas esculturas están lejos de la plasticidad que exhibe el conjunto de Porcuna o el caballo de Casas de Juan Núñez, detalles concretos, como el rostro del jinete más antiguo, muestran su deuda con prototipos griegos. También en Grecia se conocen monumentos escultóricos que presentan jinetes sin armas, como los que aparecen en la acrópolis de Atenas, aun cuando no son infrecuentes las estelas, como la famosa de Dexileo en el Cerámico de Atenas, que representa a un jinete atacando a un enemigo caído y que se data en el 394 a.C. (Knigge, 1988: 111-113) y la relación de los caballos con las tumbas aristocráticas es algo que, como veíamos, está presente desde épocas muy antiguas en Grecia. No es fácil saber si los temas iconográficos presentes en el mundo ibérico representan siempre actos o ritos reales o si, por el contrario, son una forma de representar, mediante determinadas alusiones, ideas acendradas en la religiosidad ibérica. No obstante, la presencia, no infrecuente, de arreos de caballos en muchas necrópolis ibéricas sugiere que, en el momento del enterramiento, el difunto o sus familiares no renunciaban a caracterizarle como caballero; el que no más de un $5 \%$ de tumbas ibéricas presenten arreos equinos (Quesada, 1998: 174-176) indica, fuera de toda duda, el aspecto restringido y, por ello, aristocrático de esa caracterización caballeresca. Pero también observamos cómo el mundo ibérico acabará desacralizando muchas de esas imágenes, que acabarán sirviendo de material de construcción para las tumbas de generaciones posteriores.

Otros tipos de soporte también presentan imágenes de jinetes ibéricos, como una placa de pizarra de Cástulo con un jinete inciso, en la que Blanco Freijeiro observó la fuerte influencia de la cerámica griega en la mano del individuo, quizá castulonense, que la dibujó (Blanco, 1983: 199-202). Parece, en todo caso, que el personaje representado es un lancero ibérico, aun cuando el grabador se haya inspirado en modelos que han llegado en la cerámica (Figura 14). No cabe duda de que la abundancia de temas ecuestres en las cerámicas griegas del s. IV que llegan a la Península es bastante considerable. 


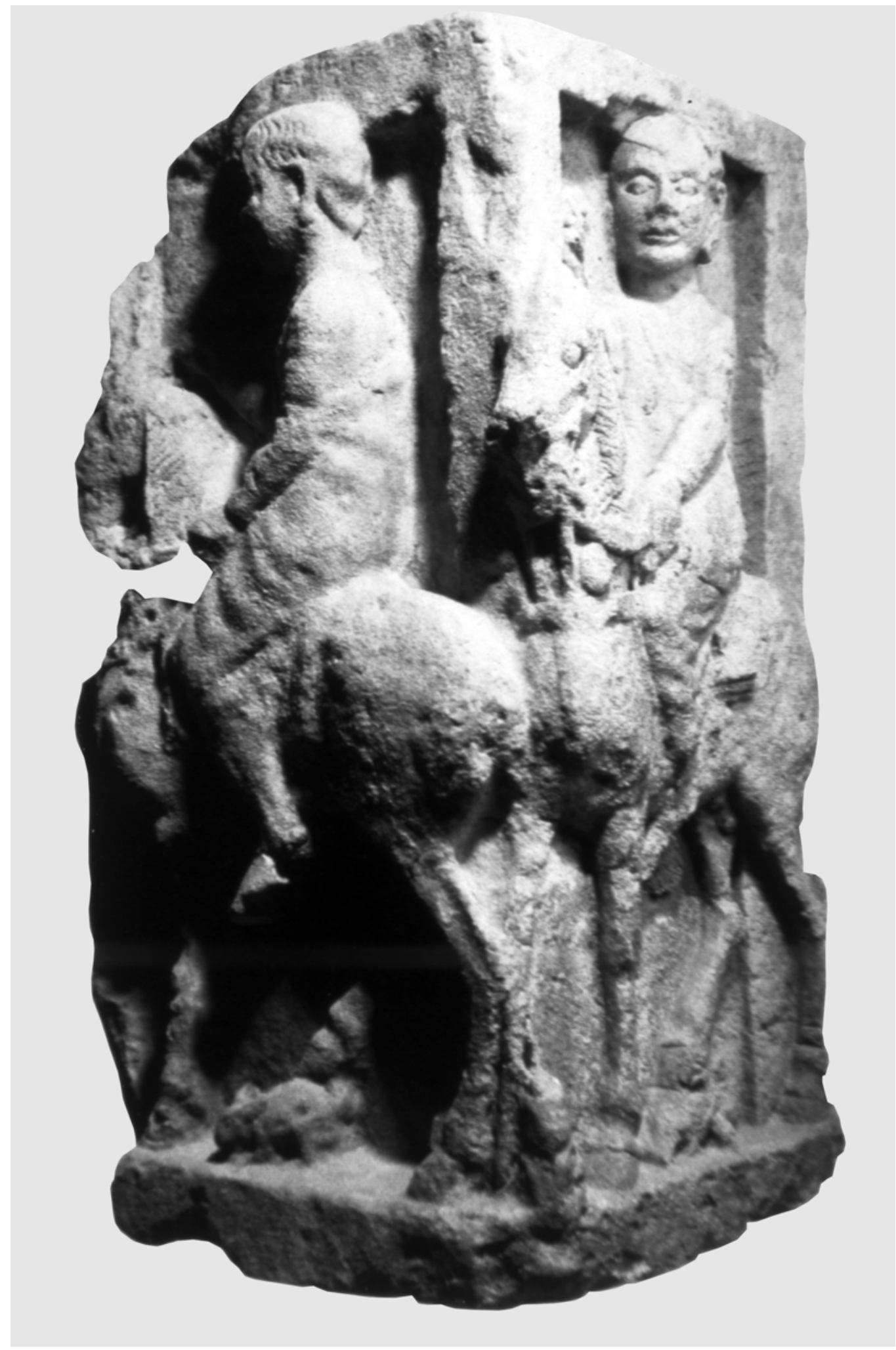

Figura 12. El pilar-estela de Coimbra del Barranco Ancho. 


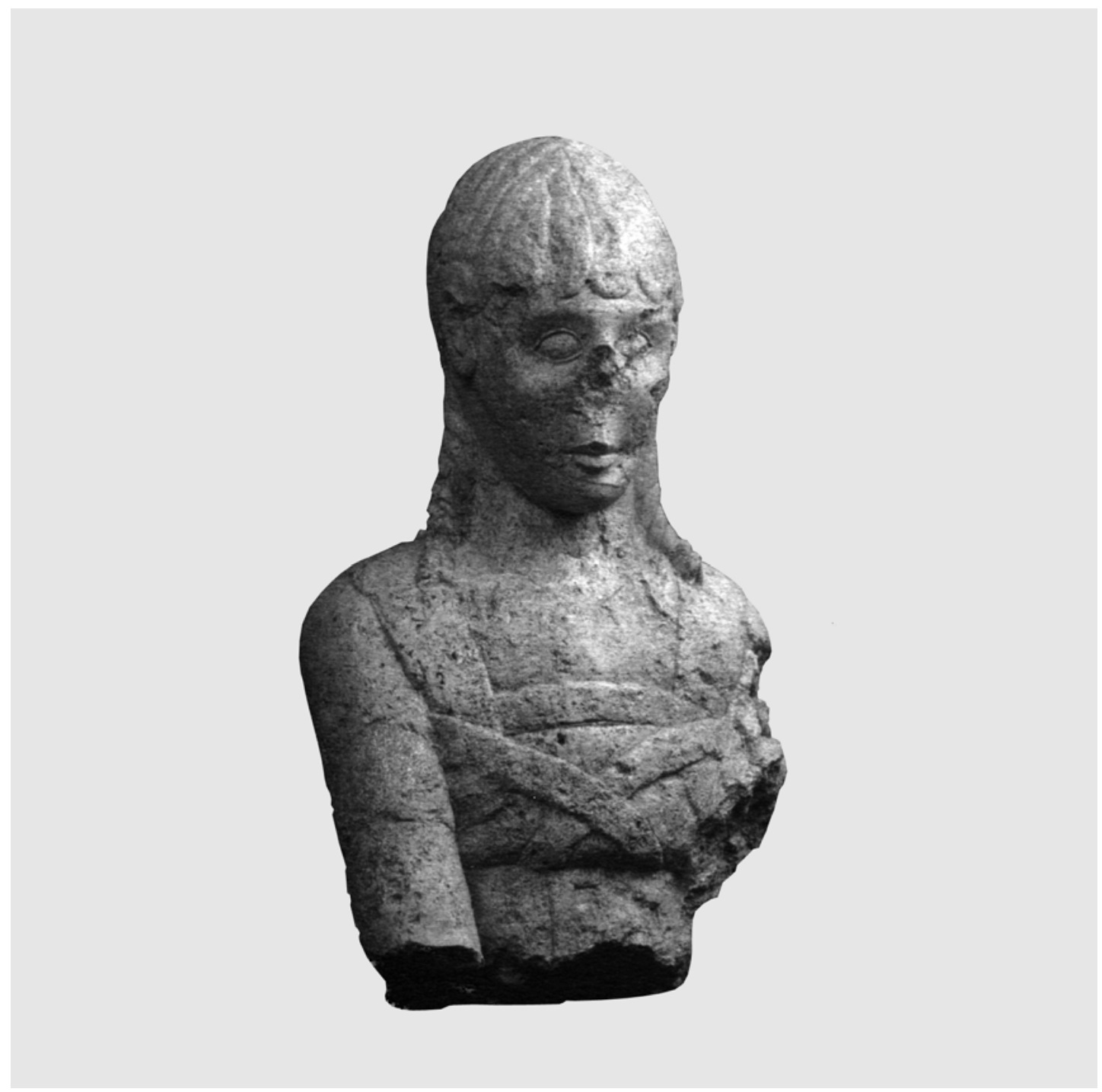

Figura 13. Jinete de la necrópolis de los Villares en Hoya Gonzalo.

En bronce hay también representaciones de jinetes, en especial en los exvotos de bronce de los santuarios de Despeñaperros, aunque en porcentajes muy escasos (Quesada, 1998: 173-174), habiendo también algún modelo de carro de dos ruedas. Para un momento ya avanzado disponemos de las representaciones de cuadrigas en una de las páteras de Tivissa o de centauresas, en la de Santisteban del Puerto, cuyos prototipos mediterráneos, o más precisamente griegos, aunque quizá a través del intermediario púnico no pueden dejar de observarse (Griñó, Olmos, 1982: 11-111; Olmos, 1997: 91-102).

De entre esas figuras en bronce destaca sobremanera el guerrero de la Bastida de les Alcuses, datable a fines del s. IV, que presenta un casco de alta cimera y empuña una falcata. La falcata es un arma que usan tanto jinetes como infantes (Quesada, 1992; Gracia, 2003: 28-29), aunque su paralelo en Grecia es un arma sobre todo de caballería; no puede establecerse una relación directa entre el mundo griego y el ibérico en este aspecto aunque no deja de llamar la atención la relación, en especial si consideramos que muchas falcatas llevan su 
empuñadura decorada con cabezas de caballo. Una combinación de estos elementos diversos la encontramos en la tumba 11 de la necrópolis de Galera, en la que aparece una crátera griega con escena ecuestre en el ajuar de una tumba que contenía entre otros objetos y junto a la urna, una copa griega (Figura 15), un par de bocados de caballo y una falcata, habiendo sugerido Olmos (1992: 77) que el difunto, que habría sido sin duda un caballero, podría haberse identificado, reinterpretándola, con la figura que representaba la crátera que acompañaba en la tumba a sus restos; no obstante, los análisis realizados sobre los restos óseos de la tumba, que parecen haber mostrado que corresponden a una mujer joven (Pereira et al., 2004: 84) ponen en suspenso dicha hipótesis y sugiere que las ideas funerarias expresadas por los iberos a través de la selección de los objetos de su ajuar resultan mucho más complejas que lo que una consideración mecanicista de tales objetos permitiría sugerir.

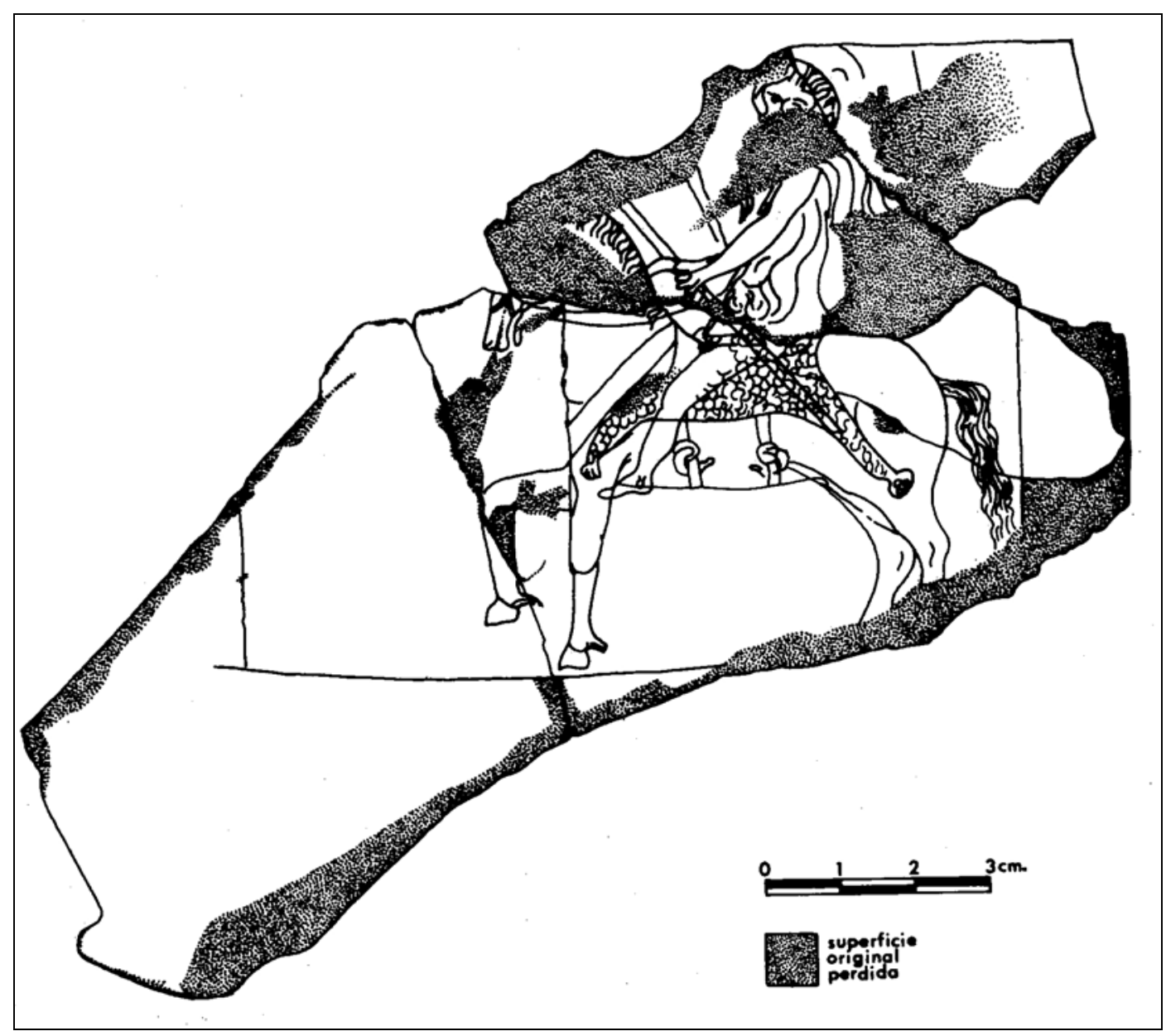

Figura 14. Placa de pizarra con la representación de un jinete procedente de Castulo.

La importancia, social y económica, del caballo en Iberia se observa en la abundancia de representaciones de équidos en diversos santuarios, como el Cigarralejo (Cuadrado, 1950; Blánquez y Quesada, 1999: 175-189; Lillo, Page y García Cano, 2004) o en Cancho Roano, donde los elementos vinculados al caballo son muy numerosos (Maluquer de Motes, 1985: 
65-69; Celestino y Julián, 1991: 179-188; Blech, 2003: 159-192), pero también en los varios relieves que muestran una posible divinidad hipotrófica, también presente en alguna decoración cerámica (Cuadrado, 1954: 797-810; Eiroa, 1988: 105-115; Marín y Padilla, 1997: 461494) (Figura 16). Es el de la o las divinidades vinculadas a los caballos uno de los pocos casos en los que podemos detectar imágenes de divinidades en el mundo ibérico, cuyas iconografías divinas resultan tan difíciles de identificar (Domínguez, 1995: 78-80).

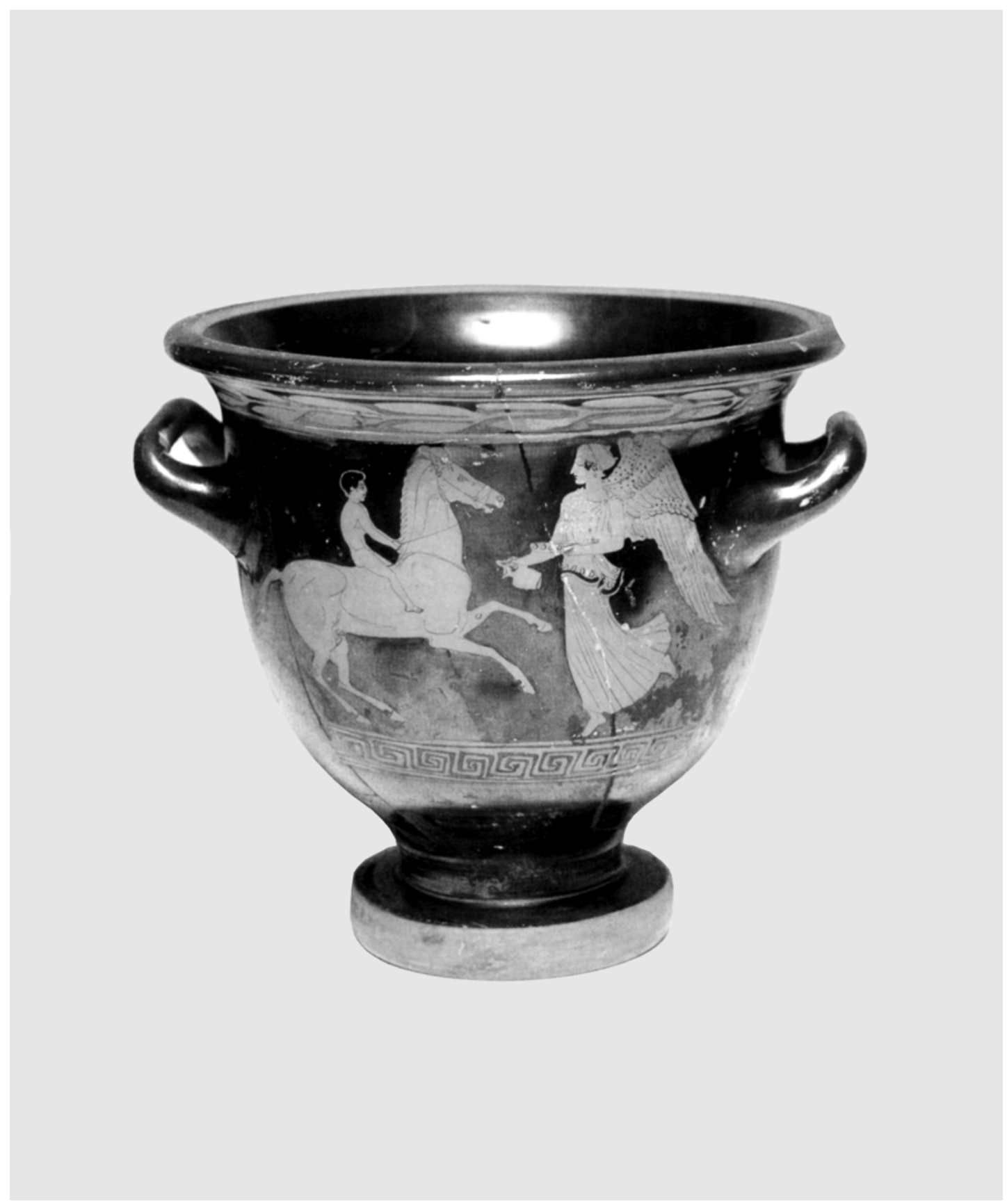

Figura 15. Crátera ática procedente de la tumba 11 de la necrópolis de Galera. 


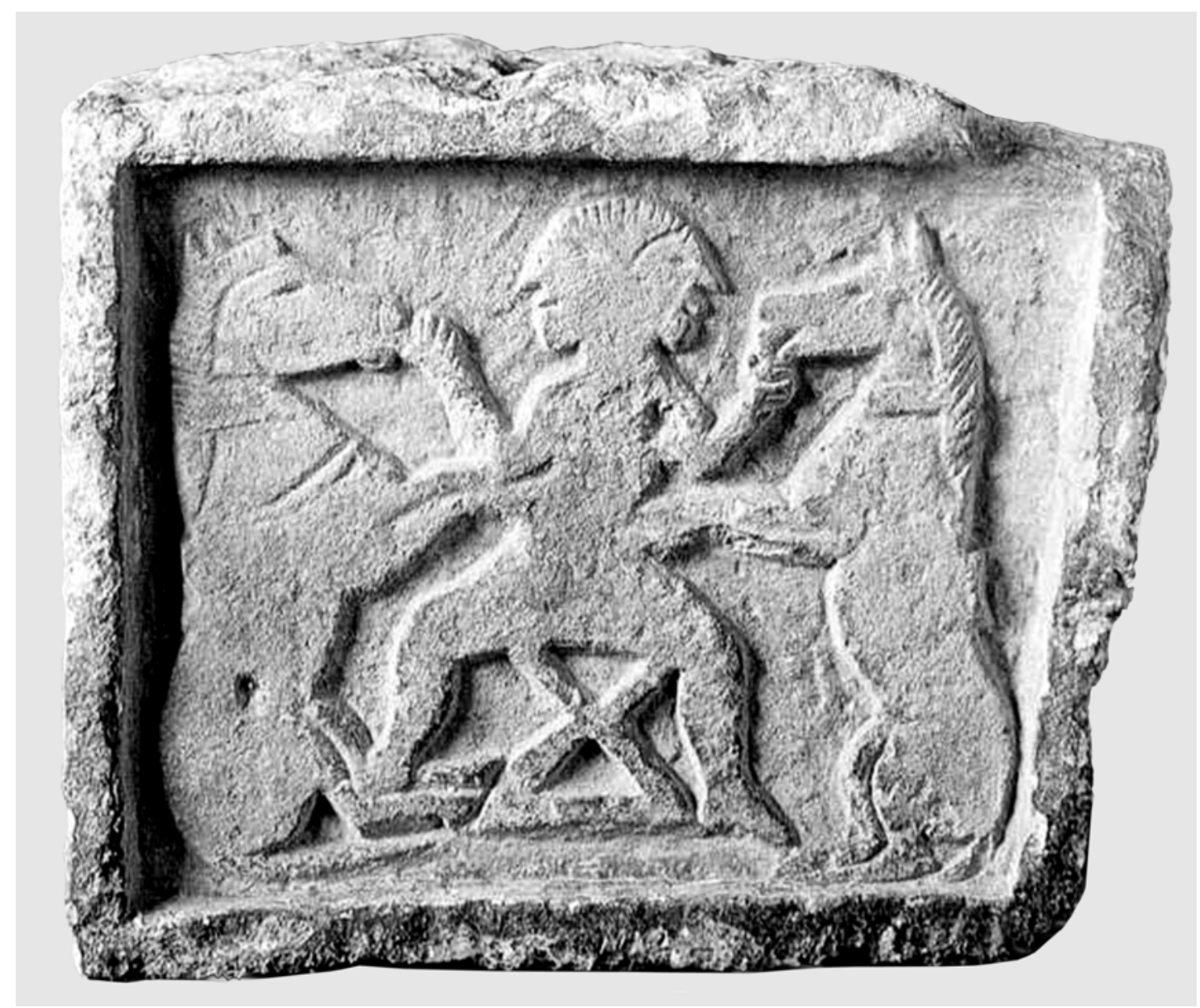

Figura 16. Posible divinidad protectora de los caballos procedente de Villaricos.

\section{OBSERVACIONES CONCLUSIVAS.}

Para concluir el presente análisis, podríamos decir que el uso de la caballería en Grecia y en el mundo ibérico sigue caminos diferentes, en el que pocas relaciones directas existen. En Grecia, el uso del caballo con fines bélicos es muy antiguo y, aunque no siempre el caballo se haya usado como animal de monta, los guerreros montados en carros tirados por caballos o, en su momento, a lomos de los mismos, han constituido siempre un elemento de distinción; sólo el paso del tiempo y el perfeccionamiento y mayor complejidad de las tácticas militares irán convirtiendo a guerreros a caballo en una auténtica caballería ya en los albores del Helenismo.

Por su parte, el caso ibérico presenta un compromiso entre lo que sin duda es un desarrollo autóctono del uso del caballo y las influencias que vendrán de los ambientes mediterráneos que accederán a lo largo del primer milenio a.C. a los ámbitos peninsulares. El hecho de que buena parte de las informaciones de que disponemos sean arqueológicas e iconográficas nos impide conocer muchos detalles del uso que al caballo como arma de guerra daban los iberos; no obstante, el caballo parece haber sido un elemento de distinción empleado por individuos ilustres en la guerra, si bien no sabemos con absoluta precisión de qué modo y, sobre todo, objeto de representación en monumentos que tuvieron como finalidad marcar las tumbas de tales personajes ilustres y exhibir el mensaje ideológico que los mismos querían difundir entre sus contemporá- 
neos y la posteridad. En estas representaciones figuradas, al menos, la relación con los prototipos helénicos parece evidente dentro del contexto general de préstamo de elementos expresivos foráneos por parte del mundo ibérico. A ello puede haber contribuido, aunque es difícil saber de qué modo, la difusión de iconografías ecuestres en los artículos de origen griego que eran usados por las élites ibéricas, de entre los que resaltan, por su mejor conservación, las cerámicas. Si, como apuntábamos antes, en algunos momentos y lugares ha podido existir una correlación entre la imagen representada en el objeto exótico y la caracterización fúnebre asumida por el difunto, ello podría corroborar cómo las imágenes griegas pudieron haber tenido una vida propia dentro del universo ideológico ibérico. Por otro lado, en las representaciones en piedra de jinetes ibéricos hay también un claro referente helénico, por más que reinterpretado a la ibérica, que puede mostrar cómo más allá de las fronteras culturales o lingüísticas, un tipo iconográfico adaptado a unas élites en Grecia podía también asumir significados equivalentes en los confines más occidentales de la ecúmene.

Adolfo J. Domínguez Monedero

Universidad Autónoma de Madrid

\section{BIBLIOGRAFÍA}

ANDERSON, J.K. (1961): Ancient Greek Horsemanship. Berkeley.

ANDERSON, J.K. (1975): «Greek Chariot-Borne and Mounted Infantry». American Journal of Archaeology, 79: 175-187.

Beckman, G.M.; Hoffner, H.A. (1999): Hittite Diplomatic Texts. $2^{\text {a }}$ ed. Atlanta.

BERnABÉ, A. (1996): «Estructura del léxico micénico sobre el carro y sus partes». Atti e Memorie del Secondo Congresso Internazionale di Micenologia. Vol. I. Roma: 195-207.

BirChall, A. (1972): «Attic horse-head amphorae». Journal of Hellenic Studies, 92: 46-63.

Blanco Freijeiro, A. (1983): «Un jinete ibérico de Cástulo». Lucentum, 2: 199-202.

BLÁNQUEZ PÉREZ, J. (1992): «Nuevas consideraciones en torno a la escultura ibérica». Cuadernos de Prehistoria y Arqueología de la Universidad Autónoma de Madrid, 19: 121-143.

BLÁNQUEZ PÉREZ, J. (1993): «El mundo funerario albacetense y el problema de la escultura ibérica. La necrópolis de los Villares». Arqueología en Albacete. Toledo: 111-128.

BLÁNQUEZ PÉREZ, J. (1995): «La necrópolis tumular ibérica de Los Villares (Hoya Gonzalo, Albacete)». El Mundo Ibérico. Una nueva imagen en los albores del año 2.000. Toledo: 238-245.

BLÁNQuez PÉREZ, J.; QueSADA SANZ, F. (1999): «El Santuario Ibérico de el Cigarralejo. Nuevas perspectivas en su estudio». J. Blánquez, L. Roldán (eds.) La Cultura Ibérica a través de la fotografía de principios de siglo. Las colecciones madrileñas. Madrid: 175-189.

Blech, M. (2003): «Elementos de atalaje de Cancho Roano». S. Celestino Pérez (ed.) Cancho Roano IX. Los Materiales Arqueológicos II. Mérida: 159-192.

BLEgEn, C.W. (1952): «Two Athenian Grave Groups of about 900 B.C.» Hesperia, 21: 279-294.

BouZEK, J. (1959): «Die attisch-geometrische Keramik im Nationalmuseum im Prag und in den anderen Tschechoslowakischen Sammlungen. Anhang I. Zu den Pyxiden mit Deckelpferden». Acta Musei nationalis Pragae,13: 131-136.

CAMP, J.M. (1998): Horses and Horsemanship in the Athenian Agora. Princeton.

CAWKWELL, G.L. (1972): «Epaminondas and Thebes». Classical Quarterly, 66: 254-278.

CELESTINo PÉREZ, S. (2001): Estelas de guerrero y estelas diademadas. La precolonización y la formación del mundo tartésico. Barcelona.

Celestino Pérez, S.; Julián RodríGUeZ, J.M. (1991): «El caballo de bronce de Cancho Roano». Cuadernos de Prehistoria y Arqueología de la Universidad Autónoma de Madrid, 18: 179-188. 
Chamoux, F. (1955): L'aurige de Delphes. (Fouilles de Delphes, IV, 5). Paris.

CONTER, C.N. (2003): Chariot Usage in Greek Dark Age Warfare. Diss. Florida State University.

Courbin, P. (1957): «Une tombe géometrique d'Argos». Bulletin de Correspondance Hellenique, 81: 322-386.

Crouwel, J.H. (1992): Chariots and other wheeled vehicles in Iron Age Greece. Amsterdam.

CuAdRADo DíAz, E. (1950): Excavaciones en el santuario ibérico del Cigarralejo (Mula, Murcia). (Informes y Memorias de la Comisaría General de Excavaciones Arqueológicas, 21). Madrid.

Cuadrado Diaz, E. (1956): «La diosa ibérica de los caballos». IV Congreso Internacional de Ciencias Prehistóricas y Protohistóricas. Zaragoza: 797-810.

Domínguez Monedero, A.J. (1995): «Religión, Rito y Ritual durante la Protohistoria Peninsular. El Fenomeno Religioso en la Cultura Ibérica». W.H. Waldren, J.A. Ensenyat, R.C. Kennard (eds.), Ritual, Rites and Religion in Prehistory, vol. 2. British Archaeological Reports, 611. Oxford: 21-91.

Domínguez Monedero, A.J. (1999): «Grecia Arcaica». Historia del mundo clásico a través de sus textos. Vol. 1. Madrid: 13-285.

Domínguez Monedero, A.J. (2001): Solón de Atenas. Barcelona.

Domínguez Monedero, A.J.; SÁnchez Fernández, C. (2001): Greek Pottery from the Iberian Peninsula. Archaic and Classical Periods. Leiden.

DORIA, M. (1972): Carri e ruote negli inventari di Pilo e di Cnosso. Trieste.

Drews, R. (1993): The End of the Bronze Age. Changes in Warfare and Catastrophe ca. 1200 B.C. Princeton.

DRIESSEN, J. (1986-87): «Observations on 'simili-joins' in the Room of the Chariot Tablets at Knossos». Studies in Mycenaean and Classical Greek presented to J. Chadwick. Minos, 20-22: 151-162.

DRIESSEN, J.M. (1988): «The scribes of the 'Room of the Chariot Tablets'«. Texts, tablets and scribes. Studies in mycenaean epigraphy and economy offered to E.L. Bennet, Jr. Salamanca: 123-165.

DUCREY, P. (1985): Guerre et guerriers dans la Grèce antique. Friburgo.

EIrOA, J.J. (1988): «Los relieves del Potnios Hippon de Lorca (Murcia)». Homenaje al Prof. Eduardo Ripoll Perelló, II. Espacio, Tiempo y Forma. Serie II, 1: 105-115.

FAgAN, P.L. (2001): Horses in the similes of the Iliad: A case study. Diss. Univ. Toronto.

FAustoferri, A. (2000): «Artisti Ionici itineranti». F. Krinzinger (ed.) Die Ägäis und das Westliche Mittelmeer. Beziehungen und Wechselwirkungen 8. bis 5. Jh. v.Chr. Viena: 315-324.

García CANO, J.M. (1994): «El pilar estela de Coimbra del Barranco Ancho (Jumilla, Murcia)». La Escultura Ibérica. Revista de Estudios Ibéricos, 1: 173-201.

García Cano, J.M. (1997): Las necrópolis ibéricas de Coimbra del Barranco Ancho (Jumilla. Murcia). I. Las excavaciones y estudio analítico de los materiales. Murcia.

GARRIDO ROIZ, J.P.; ORTA GARCÍA, E.M. (1978): Excavaciones en la necrópolis de 'La Joya', Huelva. II. (3 ${ }^{a}, 4^{a}$ y $5^{a}$ campañas). (Excavaciones Arqueológicas en España, 96). Madrid.

GIESECKE, H.E. (1988-89): «Der mykenische Wagen». Talanta, 20-21: 17-39.

González Navarrete, J.A. (1987): Escultura ibérica del Cerrillo Blanco. Porcuna, Jaén. Jaén.

Gracia Alonso, F. (2003): La guerra en la Protohistoria. Héroes, nobles, mercenarios y campesinos. Barcelona.

Greenhalgh, P.A.L. (1973): Early Greek Warfare, Horsemen and Chariots in the Homeric and Archaic Ages. Cambridge.

GriÑó, B. De; Olmos Romera, R. (1982): «La pátera de Santisteban del Puerto (Jaén)». Estudios de Iconografía, I. Madrid: 11-111.

Gulizio, J.; Pluta, K.; Palaima, T.G. (2001): «Religion in the room of the Chariot Tablets». R. Laffineur, R. Hägg (eds). POTNIA. Deities and Religion in the Aegean Bronze Age. Aegaeum, 22: 453-461. 
GÜterbock, H.G. (1983): «The Hittites and the Aegean World: Part 1. The Ahhiyawa Problem Reconsidered». American Journal of Archaeology, 87: 133-138.

HAMMOND, N.G.L. (1968): «The campaign and the battle of Marathon». Journal of Hellenic Studies, 88: 13-57.

Hanson, V.D. (1999): Les Guerres Grecques. 1400-146 av. J.-C. París.

Helbig, W. (1904): Les hippeis Athéniens. París.

Hemingway, S. (2004): The Horse and the Jockey from Artemision. A Bronze Equestrian Monument of the Hellenistic Period. Berkeley..

IZQUIERDO PERAILE, I. (2000): Monumentos funerarios ibéricos: los pilares-estela. (Trabajos Varios del S.I.P., 98). Valencia.

JENKINS, I. (1994): The Parthenon Frieze. Londres.

KARAGEORGHIS, V. (1967-1978): Excavations in the necropolis of Salamis, I-IV. Nicosia.

Knigge, U. (1988): The Athenian Kerameikos. History. Monuments. Excavations. Atenas.

KRENTZ, P. (1982): The Thirty at Athens. Londres.

Kroll, J.H. (1977): «An Archive of the Athenian Cavalry». Hesperia, 46: 63-140.

L'Allier, L. (2004): «Des chevaux et des hommes. Sur les couples hommes-chevaux et femmesjuments chez Xénophon». B. Santillo Frizell (ed.) PECUS. Man and animal in antiquity. Roma: 129-134.

LANGDOn, S. (Ed.) (1993): From pasture to polis. Art in the Age of Homer. Columbia.

LEJEUNE, M. (1968): «Chars et roues à Cnossos: structure d'un inventaire». Minos, 9: 9-61

Lillo Carpio, P.A.; PAge Del Pozo, V.; García CANO, J.M. (2004): El caballo en la sociedad ibérica. Una aproximación al Santuario de El Cigarralejo. Murcia.

LitTAUER, M. (1972): «The Military Use of the Chariot in the Aegean in the Late Bronze Age». American Journal of Archaeology, 76: 145-157.

Littauer, M.; Crouwel, J.H. (1983): «Chariots in Late Bronze Age Greece». Antiquity, 57: 187-192.

LitTAuer, M.A.; Crouwel, J.H. (1996): «Robert Drews and the role of chariotry in Bronze Age Greece». Oxford Journal of Archaeology, 15: 297-305.

Macinnes, J. (1911): «The Athenian Cavalry in the Peloponnesian War and at Amphipolis». Classical Review, 25: 193-195.

Maluquer De Motes, J. (1985): «Un artista extremeño de hace dos mil quinientos años. Estudios de Arqueología Extremeña». Homenaje a Cánovas Pesini. Badajoz: 65-69.

Marín Ceballos, M.C.; PAdilla Monge, A. (1997): «Los relieves del 'domador de caballos' y su significación en el contexto religioso ibérico». Espacios y lugares cultuales en el mundo ibérico. Quaderns de Prehistòria i Arqueologia de Castelló, 18: 461-494.

MORENO HERNÁNDEZ, J.J. (2004): «La caballería macedonia: teoría y práctica». Gladius, 24: 109-122.

MuÑoz AmiliBiA, A.M. (1988): «La escultura funeraria de la necrópolis de Coimbra del Barranco Ancho (Jumilla, Murcia)». Homenaje a D. Domingo Fletcher, I. Archivo de Prehistoria Levantina, 17: 229-255.

Negueruela Martínez, I. (1990): Los monumentos escultóricos ibéricos del Cerrillo Blanco de Porcuna (Jaén). Estudio sobre su estructura interna, agrupamientos e interpretación. Madrid.

NeILs, J. (2001): The Parthenon Frieze. Cambridge.

Olmos Romera, R. (1992): La sociedad ibérica a través de la imagen. Madrid.

Olmos RomerA, R. (1997): «Las incertidumbres de los lenguajes iconográficos: las páteras de plata ibéricas». R. Olmos, J.A. Santos (eds.). Iconografía Ibérica, Iconografía Itálica: propuestas de interpretación y lectura. Madrid: p. 91-102.

PARKER, V. (1997): Untersuchungen zum Lelantischen Krieg und verwandten Problemen der frühgriechischen Geschichte. Stuttgart. 
PASCuAl GonzÁlez, J. (1997): Grecia en el siglo IV a.C. Del imperialismo espartano a la muerte de Filipo de Macedonia. Madrid.

PAYNE, S. (1990): «Field report on the Dendra horses», Celebrations of Death and Divinity in the Bronze Age Argolid. Estocolmo: 103-106.

Pereira, J.; Chapa, T.; MAdrigal, A.; Uriarte, V.; MAYORAL, V. (2004): La necrópolis ibérica de Galera (Granada). La colección del Museo Arqueológico Nacional. Madrid.

PERNIER, L. (1934): «New Elements for the Study of the Archaic Temple of Prinias». American Journal of Archaeology, 38: 171-177.

Petrakos, B. (1996): Marathon. Atenas.

POMEROY, S.B. (2002): Spartan Women. Oxford.

Popham, M.R.; CAlligas, P.G.; SACKETT, L.H. (1988-89): «Further excavation of the Toumba cemetery at Lefkandi, 1984 and 1986. A preliminary report». Archaeological Reports, 35: 117-129.

Popham, M.R.; Calligas, P.G.; SACKetT, L.H. (1993): Lefkandi II. The Protogeometric Building at Toumba. II.- The Excavation, Architecture and Finds. Londres.

Protonotariou-Deilaki, E. (1990): «The tumuli of Mycenae and Dendra. (With an appendix by S. Payne)». Celebrations of Death and Divinity in the Bronze Age Argolid. Estocolmo: 85-106.

QUESADA SANZ, F. (1992): Arma y símbolo: la falcata ibérica. Alicante.

QUESADA SANZ, F. (1997a): «De armas de guerra a vehículos al más allá: el carro ligero». $L a$ Guerra en la Antigüedad. Una aproximación al origen de los ejércitos en Hispania. Madrid: 157-164.

QueSADA SANZ, F. (1997b): «¿Jinetes o caballeros?. En torno al empleo del caballo en la Edad del Hierro Peninsular». La Guerra en la Antigüedad. Una aproximación al origen de los ejércitos en Hispania. Madrid: 185-194.

QUESADA SANZ, F. (1998): «Aristócratas a caballo y la existencia de una verdadera 'caballería' en la cultura ibérica: dos ámbitos conceptuales diferentes». C. Aranegui (ed.) Los Iberos. Príncipes de Occidente. Estructuras de poder en la sociedad Ibérica. Barcelona: 169-183.

QuesadA, F.; ZAMORA, M. (eds.) (2003): El caballo en la Antigua Iberia. Estudios sobre los équidos en la Edad del Hierro. Madrid.

RuIJGH, C.J. (1976): Chars et roues dans les tablettes mycéniennes: la méthode de la mycénologie. Amsterdam.

RuPP, D.W. (1988): «The 'royal tombs' at Salamis (Cyprus): ideological messages of power and authority». Journal of Mediterranean Archaeology, 1: 111-139.

SloAN, R.E.; DunCAN, M.A. (1978): «Zooarchaeology at Nichoria». G. Rapp, S.E. Aschenbrenner (eds.) Exccavations at Nichoria in Southwest Greece, I: Site, Environs and Techniques. Minneapolis: 60-77.

Snodgrass, A.M. (1998): Homer and the Artists. Text and picture in early Greek Art. Cambridge.

Spence, I.G. (1993): The Cavalry of Classical Greece. A Social and Military History with particular reference to Athens. Oxford.

SUNDKVIST, A. (2004): «Herding horses: a model of prehistoric horsemanship in Scandinavia and elsewhere?» B.S. Frizell (ed.) PECUS. Man and animal in antiquity. Roma: 241-249.

UCHITEL, A. (1988): «Charioteers of Knossos». Minos, 23: 47-58.

VAnhove, D.; LAPORTe, W.; Bultiauw, P.; RAEPSAEt, G.; HeMElRYK, J. (1992): «Las disciplinas deportivas». El Deporte en la Grecia Antigua. La génesis del Olimpismo. Barcelona: 99-123.

WORLEY, L.J. (1994): Hippeis. The cavalry of Ancient Greece. Oxford.

ZIMMERMANN, J.L. (1989): Les chevaux dans l'art géométrique grecque. Maguncia. 